\title{
Design, synthesis and efficacy of hybrid triclosan-gold based molecules on artemisinin-resistant Plasmodium falciparum and Leishmania infantum parasites
}

Manel Ouji, ${ }^{\text {a, }}$ Sandra Bourgeade Delmas, ${ }^{\text {b, }}$ Álvaro Fernández Álvarez, ${ }^{\text {a, }}$ Jean-Michel Augereau, ${ }^{a}$ Alexis Valentin, ${ }^{\mathrm{b}, *}$ Catherine Hemmert, ${ }^{\mathrm{a}, *}$ Heinz Gornitzka, ${ }^{\mathrm{c}} *$ Françoise Benoit-Vical, ${ }^{\mathrm{a}, \mathrm{d}} *$

${ }^{\text {a }}$ LCC-CNRS, Université de Toulouse, CNRS, Toulouse, France

${ }^{\mathrm{b}}$ UMR 152 PharmaDev, Université de Toulouse, IRD, UPS, Toulouse, France

${ }^{\mathrm{c}}$ LCC-CNRS, Université de Toulouse, CNRS, UPS, Toulouse, France

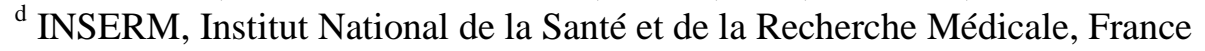

${ }^{\$}$ Participated equally to this work.

Corresponding authors: AV (alexis.valentin@univ-tlse3.fr); CH (catherine.hemmert@1cctoulouse.fr); HG (heinz.gornitzka@ 1cc-toulouse.fr); FBV (francoise.vical@inserm.fr)

\section{GRAPHICAL ABSTRACT}

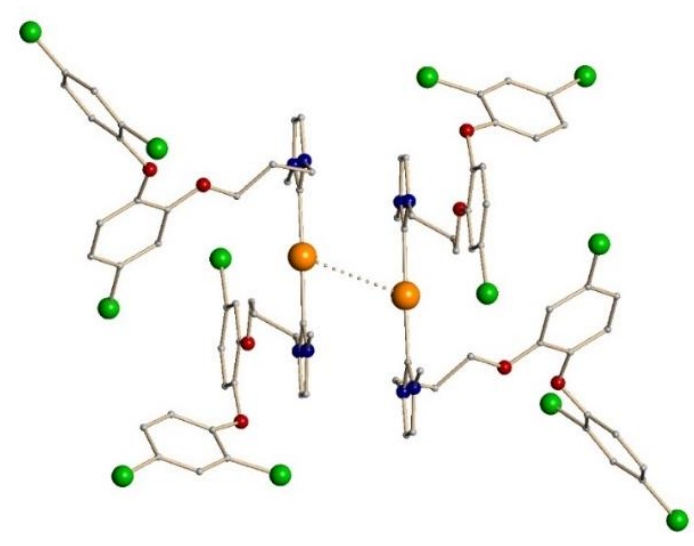

One molecule to target two pathologies. In the fight against major parasite diseases such as malaria and leishmaniasis, novel drugs active against drug-resistant parasites are needed. Hybrid molecules combining triclosan and gold(I) complexes appear as a promising avenue. 


\begin{abstract}
The emergence of resistant parasites, Plasmodium and Leishmania, responsible of malaria and leishmaniasis diseases, to the currently available drugs, remains one of the major threats to public health. Therefore, there is an urgent need to develop new molecules. Several hybrid molecules combining triclosan and gold(I) complexes have been synthesized and evaluated, in vitro, for their activities on $P$. falciparum and $L$. infantum parasites. The obtained results showed a good activity of the compounds. However, the cytotoxicity assays suggest a structure modulation to improve the selectivity. The synthesized molecules were also tested in a context of Plasmodium falciparum artemisinin-resistance and the results showed no cross-resistance induced between one gold(I) complex and artemisinin. This highlights that these compounds appear as a strong basis for further pharmacomodulation work to propose molecules targeting resistant parasites.
\end{abstract}




\section{INTRODUCTION}

Malaria and leishmaniasis are among the most important parasitic diseases through the world. ${ }^{[1]}$ Because they are co-endemic in many countries, develop drugs targeting these two diseases appears as a promising goal.

Indeed, in on one hand, malaria is the parasitic disease with the largest global epidemic impact with 3.2 billion people who are at risk of infection. Around half of the world's population can contract this disease leading to about 438,000 deaths in 2017. ${ }^{[1]}$ Plasmodium falciparum, widespread in tropical and sub-tropical regions, is the main causative agent of malaria mortality and morbidity mostly affecting children under five years.

The introduction of artemisinin and its derivatives contributed to the notable decrease of malaria mortality for the 20 last years. To reduce the risk of falciparum malaria drug resistance, the WHO recommended in 2001 to use ACTs (Artemisinin-based Combination Therapies) combining artemisinin derivatives with one or two other antimalarial drugs having different mode of action and pharmacokinetic properties. ${ }^{[2]}$ However, the efficacy of these drug combinations declined in SouthEast Asia since 2006, due to the emergence and rapid spread of $P$. falciparum resistance to artemisinins and partner drugs. ${ }^{[3]}$ This situation is increasingly alarming because, today, the most commonly used ACT in Asia, dihydroartemisinin-piperaquine, is no longer active on artemisininresistant parasites ${ }^{[4,5]}$ According to the countries, the ACTs failure rate is now up to $10 \%$ for one ACT, for two ACTs and even for the 5 ACTs. ${ }^{[6]}$

Usually, in malaria resistances, drug resistant parasites are able to proliferate and multiply during treatment but in the case of artemisinins resistance, the involved mechanism is quiescence-based. ${ }^{[7-9]}$ When treating parasites with artemisinin, most of them die, except a sub-set able to escape the treatment by a cell cycle arrest and then to resume their development when the drug is removed leading to clinical failures in the field ${ }^{[8,10]}$ Focus on artemisinin-resistant parasites is thus essential to fight malaria.

A previous work demonstrated the involvement of lipid metabolism and respiratory chain in artemisinin resistance quiescence-based. ${ }^{[1]}$ Therefore, targeting these two biochemical pathways appeared as a great avenue to develop new antimalarials. Indeed, the bacterial-like type II fatty acid synthesis (FASII) of the $P$. falciparum apicoplast, ${ }^{[12]}$ is a pretty interesting drug target because of its difference from the mammalian type I system. FASI pathway is composed of a single enzyme complex; conversely, FASII pathway uses several mono-functional proteins. ${ }^{[13]}$ Interestingly, Chen et al. have shown, in vitro, that among the genes remaining actively transcribed in dihydroartemisinininduced quiescent parasites, those coding for the FASII pathway were found. ${ }^{[1]}$ In addition, they demonstrated that treating quiescent parasites with FASII inhibitors, triclosan (TC), an antibacterial and anti-fungal agent, and haloxyfop delayed their recrudescence. Moreover, mitochondria seems also to remain active during quiescence, and could contribute to the survival and the recovery of the quiescent parasites after treatment. ${ }^{[11,14]}$

That is why this work focused on cationic gold(I) $N$-heterocyclic carbene (NHC) complexes because they act by inhibiting specifically the mitochondrial enzyme thioredoxin reductase, ${ }^{[15]}$ which plays a key role in the defense against oxidative stress. These gold(I) complexes exhibited very promising activities against several cancer cell lines. ${ }^{[16]}$ Moreover, interesting activities have been also highlighted in infectious agents including Mycobacterium, ${ }^{[17,18]}$ Plasmodium falciparum ${ }^{[19,20]}$ and Leishmania infantum ${ }^{[21,22]}$.

On the other hand, leishmaniasis have a worldwide distribution in large areas of the tropics, subtropics and Mediterranean basin, involving more than 98 countries. ${ }^{[23]}$ The burden of leishmaniasis increased over the last decades and worldwide, the population of 350 million of people is at risk. An estimated 2 million new cases occur annually with about 12 million people currently infected. ${ }^{[24]}$ Leishmaniasis due to the protozoa Leishmania, is transmitted by the bite of infected female phlebotomine sandflies that inject the infective stage, metacyclic promastigotes, during blood meals. Parasites at the puncture wound are phagocytized by macrophages and transform into amastigotes. Amastigotes multiply in infected cells and affect different tissues, depending in part on which Leishmania species is involved. 
These differing tissue specificities cause the differing clinical manifestations of the various forms of leishmaniasis such as cutaneous, ${ }^{[25]}$ mucocutaneous, or visceral ${ }^{[26]}$.

Chemotherapy is the major strategy to treat leishmaniasis including liposomal amphotericin $\mathrm{B}$, a combination of pentavalent antimonials, paromomycin, pentamidine and miltefosine and orally administrated "azoles" (ketoconazole, itraconazole, fluconazole). For cutaneous disease, paromomycin, fluconazole, or pentamidine may be effective (CDC, Ressources for Health professionals, 2018). However, their drawbacks such as limited efficacy and safety, high costs and the emergence of drug-resistant parasites encourage the urgent search for new drugs alternatives. In this way, metal-based drugs are also promising antileishmanial agents. ${ }^{[27]}$

The use of metals and their salts as antimicrobial or pathogenic agents declined sharply in the middle of the last century upon the introduction of penicillin-derived antibiotics. In the last century the use of gold-based drugs experienced an extraordinary increase with the development of new gold-based compounds such as auranofin, solganol and myochrisine for the treatment of rheumatoid arthritis. The successful application of gold(I) compounds in the treatment of rheumatoid arthritis led to the synthesis of new gold(I) and gold(III) compounds for the treatment of several diseases. It has been described that the cytotoxic effects of gold compounds are focused in a specific mitochondrial mechanism. ${ }^{[15,28]}$ Gold compounds have also been reported as antibacterial and antileishmanial agents. $^{[29]}$

The purpose is first to evaluate the activity of the homemade hybrid molecules against $P$. falciparum and L. infantum strains in vitro and secondly to focus the efficacy of the most active hybrids in a context of artemisinin resistance requiring a dedicated assay based on the malaria parasite recrudescence.

\section{RESULTS AND DISCUSSION}

\section{Chemistry}

A series of hybrid molecules gold(I)-NHC-TC was synthesized easily according to a three steps strategy (Scheme 1). First a Williamson etherification of TC with 1,3-dibromopropane was performed in dry acetonitrile at $80^{\circ} \mathrm{C}$ using a microwave reactor. TC-C3 was isolated after purification by column chromatography with a yield of $52 \%$. The proligands were then prepared by quaternization of a substituted imidazole, namely 1-methylimidazole, 1-mesitylimidazole, ${ }^{[30]}$ 1-benzylimidazole, 1 quinolinimidazole, ${ }^{[22]} 1$-thioanisolimidazole, ${ }^{[2]}$ in acetonitrile at $80^{\circ} \mathrm{C}$ for 24 to $62 \mathrm{~h}$. The imidazolium salts 1a-1e were obtained as white or beige powders with yields ranging from 43 to $67 \%$. Finally, direct metalation of the proligands with one half equivalent of $\mathrm{Au}\left(\mathrm{SMe}_{2}\right) \mathrm{Cl}$ and $\mathrm{K}_{2} \mathrm{CO}_{3}$ (1.4 equiv) in acetonitrile at $60^{\circ} \mathrm{C}$ for $16 \mathrm{~h}$ lead to the desired complexes 2a-2e with yields from 76 to $99 \%$. All the imidazolium salts 1a-1e and the complexes 2a-2e were characterized by ${ }^{1} \mathrm{H}$ and ${ }^{13} \mathrm{C}$ NMR spectra, HRMS and elemental analysis. The most characteristic feature in the ${ }^{1} \mathrm{H}$ NMR spectra are the resonances for imidazolium protons $\left(\mathrm{H}_{2}\right)$ located at 10.73, 10.35, 10.96, 12.31, and $11.32 \mathrm{ppm}$, for 1a1e, respectively. The ${ }^{13} \mathrm{C}$ NMR spectra unequivocally demonstrates the formation of the gold(I) complexes showing the resonance for the carbenic carbons at 184.03, 183.94, 183.99, 182.17, and $182.38 \mathrm{ppm}$, for $\mathbf{2 a - 2 e}$, respectively. The elemental analysis of the gold(I) complexes correspond to the general formula $\left[\mathrm{AuL}_{2}\right][\mathrm{Br}]$ and the high resolution mass spectra (ES) exhibited the classical peaks corresponding to the cations $[\mathrm{M}-\mathrm{X}]^{-}$. 
<smiles>Oc1cc(Cl)ccc1Oc1ccc(Cl)cc1Cl</smiles><smiles>C[N+](=O)[O-]</smiles><smiles>Clc1ccc(Oc2ccc(Cl)cc2OCCCBr)c(Cl)c1</smiles><smiles></smiles>

1a, $R=\operatorname{Me}(44 \%)$

1b, $R=\operatorname{Mes}(56 \%)$

1c, $R=B n(42 \%)$

1d, $R=$ Quin $(48 \%)$

1e, $\mathrm{R}=\mathrm{C}_{6} \mathrm{H}_{4} \mathrm{SMe}(67 \%)$

1

1<smiles>CN[N+](=O)[O-]</smiles><smiles>[R]N1C=CN(CC)C1CBr</smiles><smiles>ClC=CC=CC=C(Cl)CC=CCCl</smiles>

2a, $R=\operatorname{Me~}(80 \%)$
2b, $R=\operatorname{Mes}(95 \%)$

2c, $R=B n(98 \%)$

2d, R = Quin (95\%)

2e, $\mathrm{R}=\mathrm{C}_{6} \mathrm{H}_{4} \mathrm{SMe}(99 \%)$<smiles>Cl[Ge](C1N(Cc2ccccc2)C=CN1c1ccc2ccccc2n1)C1N(Cc2ccccc2)C=CN1c1ccc2ccccc2n1</smiles>

Scheme 1. Synthesis of triclosan based proligands 1a-1e and gold(I)-NHC complexes 2a-2e.

Reference complex 3.

Crystals of complex 2a suitable for X-ray diffraction analysis were obtained by slow gas-phase diffusion of diethyl ether into a saturated dichloromethane solution of complex 2a. The X-ray structure of 2a (Figure 1) shows the classic linear geometry for gold(I) with a C-Au-C angle of $178.5^{\circ}$. The gold carbon distances of 2.018 and $2.029 \AA$ are in the normal range for NHC-Au-NHC compounds. The two NHC planes are nearly coplanar with a torsion angle of $\approx 2^{\circ}$. The TC derivatives are placed in trans position looking on the NHC-Au-NHC plane and the two bulky substituents are on same side of this plane, which can be explained by the arrangement of the cations in the solid state (Figure 2). Two cations forming a dimer connected by an aurophilic interaction reflected by an $\mathrm{Au}-\mathrm{Au}$ distance of $3.503 \AA$. 


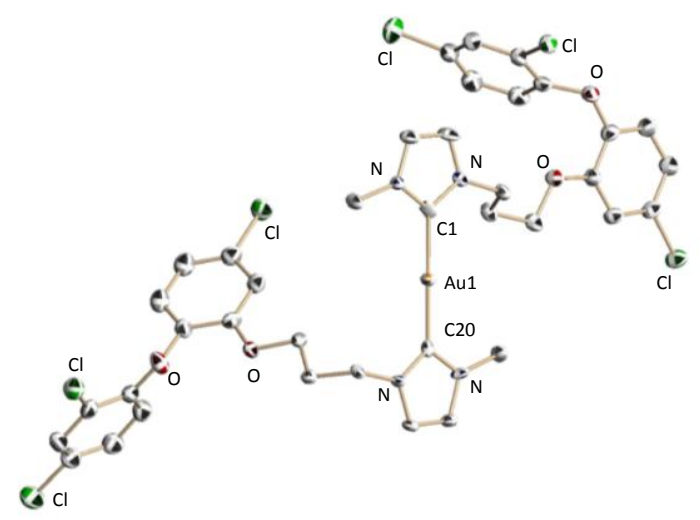

Figure 1. Crystal structure of 2a depicted at the 50\% level. Hydrogen atoms, the anion and a noncoordinating ether molecule have been omitted for clarity. Selected bond lengths $[\AA \AA]$ and angles $\left[^{\circ}\right]$ : Au-C1 2.029(6), Au-C(20) 2.018(6), C1-Au-C(20) 178.5(2).

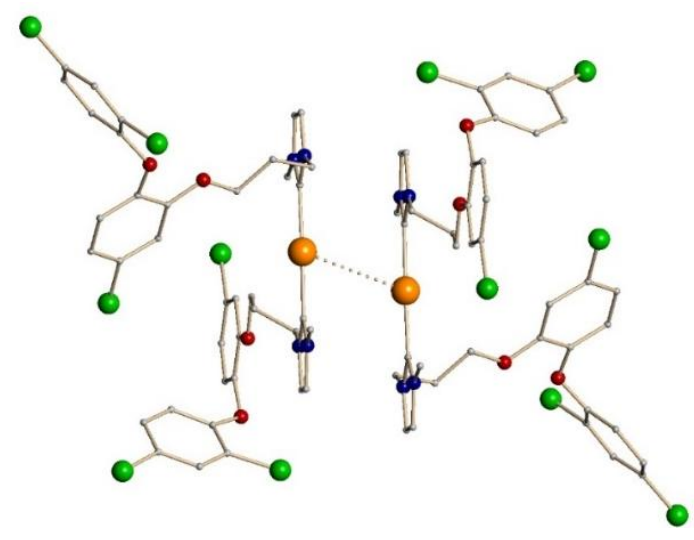

Figure 2. Dimeric arrangement of $\mathbf{2 a}$ in the solid state.

\section{Antiplasmodial activity of the compounds}

Five hybrid molecules corresponding to gold(I) complexes 2a-2e, their carbene precursors 1a-1e, and a gold(I) reference complex 3 (Scheme 1) were first screened in vitro using the $P$. falciparum strain F32-TEM (Table 1) in order to determine the $\mathrm{IC}_{50}$ and to compare to the values obtained with the antimalarial reference drug artemether and the FASII inhibitor reference molecule triclosan.

Triclosan showed a weak antiplasmodial activity with an $\mathrm{IC}_{50}$ value of $6 \mu \mathrm{M}$. These results are in accordance with a previous study which firstly studied the antiplasmodial activity of this compound ${ }^{41}$. Interestingly, when triclosan is coupled with a substituted imidazole derivative, the resulting imidazolium salts showed 6 (1c) to 18 (1e) fold higher activities against $P$. falciparum. Moreover, the corresponding gold(I) complexes showed also 4 (2b) to 50 (2a) fold better activities than triclosan. Proligand (1a) and the corresponding gold complex (2a) showed better activities with $\mathrm{IC}_{50}$ values of $343 \mathrm{nM}$ and $120 \mathrm{nM}$, respectively.

Globally, the presence of gold(I) can have opposite effects with an improvement of the efficacy comparatively to the corresponding proligand for $\mathbf{1 a}(343 \mathrm{nM})$ vs $\mathbf{2 a}(120 \mathrm{nM})$ and $\mathbf{1 c}(958 \mathrm{nM})$ vs $\mathbf{2 c}$ $(386 \mathrm{nM})$ or a deleterious effect like for $\mathbf{1 b}(382 \mathrm{nM})$ vs $\mathbf{2 b}(1465 \mathrm{nM})$, and $\mathbf{1 e}(328 \mathrm{nM})$ vs $\mathbf{2 e}(875$ $\mathrm{nM})$. In the system $1 \mathbf{d} / \mathbf{2 d}$, the $\mathrm{IC}_{50}$ values are very close, 833 and $654 \mathrm{nM}$, respectively. 
The complex $\mathbf{3}$ was synthesized as a gold(I)-NHC reference, involving a quinoline function and a benzyl group on the two nitrogen atoms of the NHCs. 3 displayed a high antiplasmodial activity with $\mathrm{IC}_{50}$ of $170 \mathrm{nM}$, a ten-fold better activity than an analog complex containing a quinoline moiety and a methyl group on the carbene $\left(\mathrm{IC}_{50}: 1 \mu \mathrm{M}\right)$ previously published ${ }^{[20]}$. Unfortunately, replacement of a benzyl substituent by a triclosan did not allow improvement of the activity of the resulting gold(I) complex 2d ( $\left.\mathrm{IC}_{50}: 654 \mathrm{nM}\right)$.

Table 1. Antimalarial and cytotoxic activities of the hybrid molecules

\begin{tabular}{|c|c|c|c|}
\hline Compounds & $\begin{array}{c}\text { Antiplasmodial } \\
\text { activity on } \\
P \text {. falciparum } \\
\text { IC }_{50} \pm \text { SEM (nM) }\end{array}$ & $\begin{array}{c}\text { Cytotoxicity } \\
\text { on Vero Cells } \\
\text { IC }_{50} \pm \operatorname{SEM}(\mathbf{n M})^{[\mathrm{b}]}\end{array}$ & $\begin{array}{c}\text { Selectivity index: } \\
\text { Vero cells / } P \text {. falciparum } \\
\text { activities }\end{array}$ \\
\hline 3 & $170 \pm 9$ & $1.1 .10^{3} \pm 0.2 .10^{3}$ & 6.5 \\
\hline 1a & $343 \pm 40$ & - & - \\
\hline $2 \mathbf{a}$ & $120 \pm 18$ & $0.9 \cdot 10^{3} \pm 0.03 \cdot 10^{3}$ & 7.5 \\
\hline $1 b$ & $382 \pm 78$ & - & - \\
\hline $2 b$ & $1465 \pm 265$ & - & - \\
\hline 1c & $958 \pm 245$ & - & - \\
\hline $2 c$ & $386 \pm 70$ & - & - \\
\hline 1d & $833 \pm 136$ & - & - \\
\hline 2d & $654 \pm 67$ & - & - \\
\hline 1e & $328 \pm 55$ & - & - \\
\hline $2 e$ & $875 \pm 51$ & - & - \\
\hline Artemether $^{[\mathrm{c}]}$ & $6.1 \pm 1$ & $214.10^{3} \pm 29.10^{3}$ & 35000 \\
\hline Triclosan & $6000 \pm 10^{3}$ & $36.10^{3}$ & 6 \\
\hline
\end{tabular}

[a] Values of $\mathrm{IC}_{50}, 50 \%$ inhibitory concentration, on Plasmodium falciparum where obtained using both SYBR Green and radioactivity assays, and correspond to the mean of at least 4 independent experiments.

[b] Cytotoxic activities of the compounds were evaluated against Vero cell line.

[c] Artemether, the antiplasmodial control drug, was routinely tested.

\section{Antileishmanial activity of the compounds}

The cationic Au(I)bis(NHC-TC) 2a-2e and their carbene precursors 1a-1e complexes were screened in vitro on both the promastigote and the axenic amastigote stages of $L$. infantum, by determining their $\mathrm{IC}_{50}$ values and compare to three different antileishmanial reference drugs, namely, amphotericin $\mathrm{B}$, 
pentadimine and miltefosine as well as the pharmacophore triclosan and the gold drug reference auranofin. The results are summarized in table 2.

All compounds were firstly tested against promastigotes of $L$. infantum showing moderate or no activity with $\mathrm{IC}_{50}$ values from $5.51 \mu \mathrm{M}$ for $2 \mathrm{a}$ to $63.87 \mu \mathrm{M}$ for $\mathbf{2 b}$. Looking at the activities against promastigotes of the proligand/complex couples, there was just one clear enhanced activity by addition of gold(I) in the case of the methyl substituted couple 1a-2a, complex 2a being the most active complex. Then all compounds were tested against the relevant axenic amastigote form of $L$. infantum. Except 1a, all proligands displayed high activities in the low micro- and submicromolar range $\left(\mathrm{IC}_{50}\right.$ values from 0.57 to $\left.1.10 \mu \mathrm{M}\right)$. The same tendency could be observed for the gold complexes with $\mathrm{IC}_{50}$ values ranging from 0.21 to $1.54 \mu \mathrm{M}$, excluding the mesityl substituted gold(I) complex $\mathbf{2 b}$ with an $\mathrm{IC}_{50}$ of $11.62 \mu \mathrm{M}$. Comparing to their respective proligands against axenic amastigotes, two complexes were more active ( $\mathbf{2 a}$ and $\mathbf{2 e}$ ), two were less active (2b and $\mathbf{2 c}$ ), while one showed the same activity (2d). Regarding these data, the role of gold(I) could not be totally established in relation with the amastigote activity. Nevertheless, the two most active gold(I) complexes of this series towards the clinically relevant axenic amastigote form of $L$. infantum are $\mathbf{2 a}$ $\left(\mathrm{IC}_{50}=0.21 \mu \mathrm{M}\right)$ and $\mathbf{2 e}\left(\mathrm{IC}_{50}=0.39 \mu \mathrm{M}\right)$ and these $\mathrm{TC}$ derivates complexes (except $\left.\mathbf{2 b}\right)$ are globally as efficient as the two commercial drugs pentadimine and miltefosine.

These $\mathrm{Au}(\mathrm{I})$ bis(NHC-TC) series had similar activity to previously reported cationic $\mathrm{Au}(\mathrm{I}) \mathrm{bis}(\mathrm{NHC})$ and neutral $\mathrm{Au}(\mathrm{I})(\mathrm{NHC}) \mathrm{Cl}$ complexes including aliphatic and aromatic substituents. ${ }^{[21,22]}$ This suggests that no enhanced activity was found by addition of the triclosan moiety.

Table 2. In vitro antileishmanial activity and cytotoxicity of compounds $1 \mathbf{1 a - 2 e}$ and $\mathbf{2 a - 2 e}$

\begin{tabular}{|c|c|c|c|c|c|c|}
\hline Compounds & $\begin{array}{l}\text { L. infantum } \\
\text { promastigotes } \\
\qquad \mathrm{IC}_{50}(\mu \mathrm{M})^{\mathrm{a}}\end{array}$ & $\begin{array}{c}\text { J774A.1 } \\
\mathrm{CC}_{50}(\mu \mathrm{M})^{\mathrm{a}}\end{array}$ & $\begin{array}{c}\text { Selectivity index } \\
\text { promastigotes } \\
\mathrm{CC}_{50} / \mathrm{IC}_{50} \\
\text { (Pro) }\end{array}$ & $\begin{array}{c}\text { L. infantum } \\
\text { axenic amastigotes } \\
\qquad \mathrm{IC}_{50}(\mu \mathrm{M})^{\mathrm{a}}\end{array}$ & $\begin{array}{c}\text { Selectivity index } \\
\text { amastigotes } \\
\mathrm{CC}_{50} / \mathrm{IC}_{50} \\
\text { (Ama) }\end{array}$ & $\begin{array}{c}\text { Selectivity index } \\
\text { Ama/Pro } \\
\text { IC }_{50}(\mathbf{P r o}) / \text { IC }_{50} \\
\text { (Ama) }\end{array}$ \\
\hline $1 \mathbf{a}$ & $42.27 \pm 2.67$ & $5.92 \pm 1.35$ & 0.14 & $8.47 \pm 0.42$ & 0.70 & 4.99 \\
\hline $2 \mathbf{a}$ & $5.51 \pm 0.12$ & $0.21 \pm 0.04$ & 0.04 & $0.21 \pm 0.02$ & 1.03 & 26.65 \\
\hline $1 b$ & $7.17 \pm 1.12$ & $0.69 \pm 0.10$ & 0.10 & $0.57 \pm 0.11$ & 1.2 & 12.51 \\
\hline $2 b$ & $63.87 \pm 6.25$ & $3.76 \pm 0.20$ & 0.06 & $11.62 \pm 0.98$ & 0.32 & 5.50 \\
\hline $1 \mathrm{c}$ & $13.38 \pm 0.89$ & $1.43 \pm 0.96$ & 0.11 & $0.90 \pm 0.03$ & 1.59 & 14.81 \\
\hline $2 c$ & $13.25 \pm 0.32$ & $0.96 \pm 0.08$ & 0.07 & $1.54 \pm 0.08$ & 0.63 & 8.62 \\
\hline 1d & $10.53 \pm 0.20$ & $1.29 \pm 0.21$ & 0.12 & $1.10 \pm 0.16$ & 1.17 & 9.57 \\
\hline 2d & $27.73 \pm 2.10$ & $2.27 \pm 0.41$ & 0.08 & $1.10 \pm 0.15$ & 2.05 & 25.13 \\
\hline $1 \mathrm{e}$ & $8.86 \pm 0.24$ & $1.17 \pm 0.16$ & 0.13 & $0.77 \pm 0.02$ & 1.52 & 11.46 \\
\hline $2 e$ & $6.92 \pm 1.09$ & $0.69 \pm 0.06$ & 0.10 & $0.39 \pm 0.09$ & 1.76 & 17.58 \\
\hline $\operatorname{Triclosan}^{[b]}$ & $51.36 \pm 3.41$ & $17.73 \pm 0.79$ & 0.35 & $1.49 \pm 0.20$ & 11.90 & 34.47 \\
\hline Auranofin $^{[b]}$ & $4.32 \pm 0.76$ & $2.67 \pm 0.32$ & 0.62 & $0.07 \pm 0.01$ & 38.14 & 61.71 \\
\hline Amphotericin $\mathbf{B}^{[\mathrm{c}]}$ & $0.08 \pm 0.01$ & $1.84 \pm 0.01$ & 23.59 & $0.06 \pm 0.01$ & 29.68 & 1.26 \\
\hline Pentamidine $^{[\mathrm{c}]}$ & $0.63 \pm 0.33$ & $0.87 \pm 0.03$ & 1.38 & $1.36 \pm 0.31$ & 0.64 & 0.46 \\
\hline Miltefosine $^{[\mathrm{cc}]}$ & $22.58 \pm 1.72$ & $40.68 \pm 2.61$ & 1.80 & $0.46 \pm 0.04$ & 88.43 & 49.09 \\
\hline Doxorubicin $^{[\mathrm{d}]}$ & - & $0.05 \pm 0.01$ & - & - & - & - \\
\hline
\end{tabular}

[a] Mean of three independent experiments. 
[b] Triclosan and Auranofin were used as pharmacophore and gold-based drug references, respectively.

[c] Amphotericin B, miltefosine and pentamidine were used as antileishmanial compounds of reference.

[d] Doxorubicin was used as positive control of cytotoxicity.

\section{Selectivity index of the compounds regarding their antiplasmodial and antileishmanial activities}

Concerning Plasmodium, as 2a was the most active molecule among the gold(I)-triclosan hybrids tested, its cytotoxicity was assessed on mammalian cells in order to determine the specificity of its activity (Table 1). The selectivity index (S.I.) was 7.5 for $\mathbf{2 a}$ which is comparable to 6.5 for the gold(I) complex (3) and 6 for triclosan. These low S.I. highlighted that $\mathbf{2 a}$ has a same range of activity against normal mammalian cells and $P$. falciparum.

Concerning Leishmania, complexes were tested in vitro for their cytotoxicity, measured by the $\mathrm{CC}_{50}$ on the murine J774A.1 macrophages cell line (positive control = doxorubicin), giving access to the corresponding selectivity indexes $\left(\mathrm{CC}_{50} / \mathrm{IC}_{50}\right)$. The selectivity indexes for promastigotes $\left(\mathrm{CC}_{50} / \mathrm{IC}_{50}\right.$ Pro) ranged from 0.10 to 0.14 for the proligands and from 0.04 to 0.10 for the gold(I) complexes, indicating a toxicity of the compounds and in particular the complexes. Likewise, the S.I. for amastigotes $\left(\mathrm{CC}_{50} / \mathrm{IC}_{50} \mathrm{Ama}\right)$ were from 0.32 to 2.05 , meaning that both proligands and complexes are rather toxic and not selective. The S.I. amastigote/ promastigote ranged from 4.99 to 14.81 for the proligands, and from 5.50 to 26.65 for the complexes, with increased selectivity in most cases by coordination of the gold(I) on the NHCs.

Finally, the gold reference auranofin exhibited higher activity and selectivity $\left(\mathrm{IC}_{50}\right.$ (Pro) $=4.32 \mu \mathrm{M}$, SI $=2.67$ and $\left.\mathrm{IC}_{50}(\mathrm{Ama})=0.07 \mu \mathrm{M}, \mathrm{SI}=38.14\right)$ on the two stages of $L$. infantum than all complexes, with values on the amastigote form very close to the reference drug amphotericin B. Related to the pharmacophore triclosan $\left(\mathrm{IC}_{50}(\mathrm{Pro})=51.36 \mu \mathrm{M}, \mathrm{IC}_{50}(\mathrm{Ama})=1.49 \mu \mathrm{M}\right)$, most of the complexes and ligands tested in this study showed more potency on promastigotes and most of them displayed equal (2c) or better activity $(\mathbf{1 b}-\mathbf{1 e}, \mathbf{2 a}, \mathbf{2 d}, \mathbf{2 e})$ on axenic amastigotes. For comparison, the selectivity of the simple gold(I) complexes previously reported was higher than those of these complexes including a triclosan moiety, suggesting that the incorporation of the triclosan derivative could be related with loss in selectivity, without increasing the activity.

\section{In vitro cross-resistance between hybrid molecules and artemisinin}

In a context of artemisinins resistance, including dihydroartemisinin (DHA) the active metabolite of artemisinin derivatives used in ACTs, the standard in vitro susceptibility assay based on the inhibition of parasite proliferation is not appropriated to evaluate drug resistance. ${ }^{[7,39,42]}$ Indeed, there is no significant difference between the $\mathrm{IC}_{50}$ values from a resistant-artemisinin and a sensitive-artemisinin strain. An entry into dormancy (quiescence) of a small sub-population of the parasites in presence of the drug is responsible for artemisinins resistance, parasites restarting their proliferation after elimination of this drug. That explains that classical chemo-sensitivity assays are unsuitable and the necessity for an assay evaluating the parasite abilities to proliferate after the drug removal. That is why, a relevant recrudescence assay was developed and was used here to explore the activity of the molecules against F32-ART, a highly artemisinin-resistant strain and comparatively to the artemisininsensitive line F32-TEM. ${ }^{[7,39]}$ In this test, the cross-resistance between artemisinin and another compound is demonstrated by a faster resumption of proliferation for the F32-ART strain compared to the sensitive F32-TEM strain after exposure of these strains to the molecule tested.

The 9.7 days of difference between both strains after artemisinin treatment confirmed the crossresistance between all molecules from artemisinin class. It is to note that no cross-resistance was evidenced for triclosan with similar recrudescence days ( 0.8 day of difference) for F32-ART and F32TEM (Table 3). However, this result needs to be moderated by the low activity of triclosan on $P$. falciparum (Table 1). Unfortunately, the gold(I)-triclosan complex (2a) showed a trend of cross- 
resistance with artemisinin, so neither the triclosan part, nor the gold(I) permitted to avoid this crossresistance especially highlighted at 1 and $2 \mu \mathrm{M}$ (Table 3 ).

Nevertheless, gold(I) complex 3 (table 3) didn't show cross-resistance with artemisinin. This is consistent with previous results which revealed that atovaquone, a mitochondrial electron transfer inhibitor, didn't induce any cross-resistance with artemisinins, ${ }^{[39]}$ confirming mitochondria as potential drug target to eliminate artemisinins-resistant parasites. In this way, further complexes containing gold(I) will be developed.

Table 3. Recrudescence capacity of Plasmodium falciparum F32-ART and F32-TEM strains after 48h-drug exposure ${ }^{[a]}$

\begin{tabular}{ccccccc} 
Compounds & Doses & $\begin{array}{c}\text { Number of } \\
\text { experiments }\end{array}$ & $\begin{array}{c}\text { Median (range) } \\
\text { recrudescence days }\end{array}$ & \multicolumn{2}{c}{$\begin{array}{c}\text { Mean } \pm \text { SEM difference of } \\
\text { recrudescence days }\end{array}$} & \multirow{2}{*}{$\boldsymbol{p}$-value } \\
\cline { 5 - 6 } Artemisinin & $18 \mu \mathrm{M}$ & 6 & $9.5(6-17)$ & $18.5(17->30)$ & $9.7 \pm 0.3$ & 0.006 \\
Triclosan & $7 \mu \mathrm{M}$ & 5 & $5(2-7)$ & $6(2-9)$ & $0.8 \pm 0.3$ & 0.42 \\
$\mathbf{3}$ & $1 \mu \mathrm{M}$ & 3 & $10(7-15)$ & $11(8-17)$ & $1.3 \pm 0.5$ & 0.49 \\
$\mathbf{3}$ & $2 \mu \mathrm{M}$ & 1 & 12 & 13 & 1 & \\
$\mathbf{2 a}$ & $500 \mathrm{nM}$ & 1 & 15 & 17 & 2 & \\
$\mathbf{2 a}$ & $1 \mu \mathrm{M}$ & 2 & $25->30$ & $>30$ & $>5$ & \\
$\mathbf{2 a}$ & $2 \mu \mathrm{M}$ & 1 & 16 & $>30$ & $>14$ & \\
$\mathbf{2 a}$ & $10 \mu \mathrm{M}$ & 1 & $>30$ & $>30$ & - & \\
\hline
\end{tabular}

[a] Synchronized ring-stage parasites have undergone $48 \mathrm{~h}$ of drug treatment. After that, cultures were washed and parasitemia was monitored during 30 days or until reaching the initial parasitemia, defined as the recrudescence day. If no parasites were observed at the end of the experiment, the culture was classified as showing no recrudescence, and the recrudescence day was noted as $>30$.

Data distribution was Gaussian. A log-rank (Mantel-Cox) test was used for statistical analysis of recrudescence days; $p<0.05=$ significant difference between F32-ART and F32-TEM.

\section{CONCLUSION}

A family of triclosan derivatives containing imidazolium salts and corresponding bisNHC gold(I) complexes have been synthesized, characterized and tested on $P$. falciparum and $L$. infantum parasites. Our work permitted to design new compounds for the needy portfolio of the antiplasmodial and antileishmanial drug-candidates. Very high antiplasmodial and antileishmanial activities are reported here with bisNHC gold(I); for L. infantum the level of activity was similar for some bisNHC gold(I) complexes to those of the reference compounds. However, the next structure-activity relationships should be oriented towards a better selectivity. Moreover, in a context of widespread malaria 
resistance, the upcoming new gold(I) complexes should combine pharmacophores targeting specifically the biochemistry pathways of quiescent resistant Plasmodium parasites in order to avoid cross-resistance with artemisinins. Pharmaco-modulation studies are thus in progress based on these solid and promising results in order to propose novel drugs with the maintain of high-level activities, the specificity increase and to consider the risk of cross-resistance with drugs already used in a context of worldwide resistance.

\section{MATERIALS AND METHODS}

\section{General information for synthesis}

All manipulations were performed under an inert atmosphere of dry nitrogen by using standard vacuum line and Schlenk tube techniques. 1-Mesitylimidazole, ${ }^{[30]} 1$-(quinoline-2-yl)- $1 H$-imidazole ${ }^{22}$, 1-(4-methylthiophenyl)-1H-imidazole, ${ }^{[21]}$ and 2-(3-bromopropoxy)-4-chloro-1-(2,4-dichlorophenoxy)benzene (TC-C3) ${ }^{[31]}$ were prepared as described in the literature. All other reagents were used as received from commercial suppliers. ${ }^{1} \mathrm{H}(300$ or $400 \mathrm{MHz}),{ }^{13} \mathrm{C}(75$ or $101 \mathrm{MHz}) \mathrm{NMR}$ spectra were recorded at $298 \mathrm{~K}$ on Bruker AV300, Bruker AV400, Bruker HD400 spectrometers in $\mathrm{CDCl}_{3}, \mathrm{CD}_{3} \mathrm{CN}$ or DMSO- $d_{6}$ as solvents. Elemental analyses were carried out by the "Service de Micro-analyse du Laboratoire de Chimie de Coordination (Toulouse)". High Resolution Mass Spectrometry (HRMS) analysis were performed with a Xevo G2 QTOF Waters spectrometer using electrospray ionization (ESI) by the "Service de Spectrométrie de Masse de Chimie UPS-CNRS" (Toulouse).

\section{Preparation of Imidazolium salts}

1-(3-(5-Chloro-2-(2,4-dichlorophenoxy)phenoxy)propyl)-3-methyl-2,3-dihydro-1H-imidazol-3ium bromide (1a). To a stirred solution of TC-C3 $(131.4 \mathrm{mg}, 0.32 \mathrm{mmol})$ in $\mathrm{CH}_{3} \mathrm{CN}(10 \mathrm{~mL}), 1$ methylimidazole $(25.5 \mu \mathrm{L}, 0.32 \mathrm{mmol})$ was added and the reaction mixture was stirred 1 day at $70{ }^{\circ} \mathrm{C}$. Then, the solvent was evaporated under reduced pressure and the viscous residue was purified by washing with diethylether to afford a yellow powder $(67.4 \mathrm{mg}, 43 \%$ yield). Anal. Calcd. For $\mathrm{C}_{19} \mathrm{H}_{18} \mathrm{BrCl}_{3} \mathrm{~N}_{2} \mathrm{O}_{2} \mathrm{C}, 46.33 ; \mathrm{H}, 3.68 ; \mathrm{N}, 5.69$. Found $\mathrm{C}, 46.35 ; \mathrm{H}, 3.75 ; \mathrm{N}, 5.53$. ${ }^{1} \mathrm{H}$ NMR (300 MHz, $\left.\mathrm{CDCl}_{3}\right) \delta 10.73(\mathrm{~d}, J=1.7 \mathrm{~Hz}, 1 \mathrm{H}), 7.47(\mathrm{~d}, J=2.5 \mathrm{~Hz}, 1 \mathrm{H}), 7.19-7.15(3 \mathrm{H}), 7.06-6.97(3 \mathrm{H}), 6.71(\mathrm{~d}$, $J=8.8 \mathrm{~Hz}, 1 \mathrm{H}), 4.40(\mathrm{t}, J=6.8 \mathrm{~Hz}, 2 \mathrm{H}),, 4.11-4.06(\mathrm{~m}, 2 \mathrm{H}), 4.05(\mathrm{~s}, 3 \mathrm{H}), 2.44(\mathrm{tt}, J=6.8 \mathrm{~Hz}, 2 \mathrm{H}) .{ }^{13} \mathrm{C}$ NMR (101 MHz, $\left.\mathrm{CDCl}_{3}\right) \delta 152.21$ (1C), 149.84 (1C), 142.68 (1C), 138.36 (1C), 131.06 (1C), 130.20 (1C), 128.31 (1C), 128.15 (1C), 123.98 (1C), 122.60 (1C), 122.45 (1C), 121.98 (2C), 118.12 (1C), 115.21 (1C), 65.22 (1C), 46.91(1C), 36.80 (1C), 29.65 (1C). HRMS (ES ): calcd. for $\mathrm{C}_{19} \mathrm{H}_{18} \mathrm{Cl}_{3} \mathrm{~N}_{2} \mathrm{O}_{2}$ 411.0434 found $411.0433\left[\mathrm{M}-\mathrm{Br}^{-}\right]^{+}$.

3-(3-(5-Chloro-2-(2,4-dichlorophenoxy)phenoxy)propyl)-1-mesityl-2,3-dihydro-1H-imidazol-3-

ium bromide (1b). To a stirred solution of TC-C3 (344.8 mg, $0.84 \mathrm{mmol})$ in $\mathrm{CH}_{3} \mathrm{CN}(10 \mathrm{~mL}), 1-$ mesitylimidazole $(139.7 \mathrm{mg}, 0.75 \mathrm{mmol})$ was added and the reaction mixture was stirred 2 days at 70 ${ }^{\circ} \mathrm{C}$. Then, the solvent was evaporated under reduced pressure and the residue was purified by washing with diethylether to afford a white powder ( $284.9 \mathrm{mg}$, 56\% yield). Anal. Calcd. For $\mathrm{C}_{27} \mathrm{H}_{26} \mathrm{BrCl}_{3} \mathrm{~N}_{2} \mathrm{O}_{2}$ $\mathrm{C}, 54.34 ; \mathrm{H}, 4.39 ; \mathrm{N}, 4.69$. Found C, 54.24; H, 4.45; N, 4.76. ${ }^{1} \mathrm{H}$ NMR (400 MHz, $\left.\mathrm{CDCl}_{3}\right) \delta 10.35(\mathrm{t}, J$ $=1.6 \mathrm{~Hz}, 1 \mathrm{H}), 7.74(\mathrm{t}, J=1.8 \mathrm{~Hz}, 1 \mathrm{H}), 7.44(\mathrm{~d}, J=2.5 \mathrm{~Hz}, 1 \mathrm{H}), 7.16(\mathrm{dd}, J=8.8,2.5 \mathrm{~Hz}, 1 \mathrm{H}), 7.09(\mathrm{t}$, $J=1.8 \mathrm{~Hz}, 1 \mathrm{H}), 7.04(\mathrm{~d}, J=2.3 \mathrm{~Hz}, 1 \mathrm{H}), 7.01-6.97(\mathrm{~m}, 3 \mathrm{H}), 6.93(\mathrm{~d}, J=8.5 \mathrm{~Hz}, 1 \mathrm{H}), 6.71(\mathrm{~d}, J=8.8$ $\mathrm{Hz}, 1 \mathrm{H}), 4.79(\mathrm{t}, J=6.9 \mathrm{~Hz}, 2 \mathrm{H}), 4.14(\mathrm{t}, J=5.5 \mathrm{~Hz}, 2 \mathrm{H}), 2.55(\mathrm{~m}, 2 \mathrm{H}), 2.36(\mathrm{~s}, 3 \mathrm{H}), 2.02(\mathrm{~s}, 6 \mathrm{H}) .{ }^{13} \mathrm{C}$ NMR (101 MHz, $\left.\mathrm{CDCl}_{3}\right) \delta 152.19$ (1C), 149.80 (1C), 141.50 (1C), 138.97 (1C), 134.52 (2C), 134.40 (1C), 130.86 (1C), 130.20 (1C), 129.23 (2C), 128.12 (1C), 127.96 (1C), 123.87 (1C), 123.56 (1C), 122.37 (1C), 122.15 (1C), 122.03 (1C), 121.65 (1C), 117.98 (1C), 115.20 (1C), 65.18 (1C), 45.58 (1C), 30.97 (1C), 21.16 (1C), 18.32 (2C). HRMS (ES ${ }^{+}$: calcd. for $\mathrm{C}_{27} \mathrm{H}_{26} \mathrm{Cl}_{3} \mathrm{~N}_{2} \mathrm{O}_{2} 515.1060\left[\mathrm{M}-\mathrm{Br}^{-}\right]^{+}$ found $515.1064\left[\mathrm{M}-\mathrm{Br}^{-}\right]^{+}$.

1-Benzyl-3-(3-(5-chloro-2-(2,4-dichlorophenoxy)phenoxy)propyl)-1H-imidazol-3-ium bromide (1c). To a stirred solution of TC-C3 $(307.9 \mathrm{mg}, 0.75 \mathrm{mmol})$ in $\mathrm{CH}_{3} \mathrm{CN}(10 \mathrm{~mL})$, 1-benzylimidazole 
$(86.9 \mu \mathrm{L}, 0.67 \mathrm{mmol})$ was added and the reaction mixture was stirred 3 days at $70{ }^{\circ} \mathrm{C}$. Then, the solvent was evaporated under reduced pressure and the residue was purified by washing with diethylether to afford a white powder (160.3 mg, $42 \%$ yield). Anal. Calcd. For $\mathrm{C}_{25} \mathrm{H}_{22} \mathrm{BrCl}_{3} \mathrm{~N}_{2} \mathrm{O}_{2} \mathrm{C}$, 52.80; H, 3.90; N, 4.93. Found C, 52.75; H, 3.85; N, 4.72. ${ }^{1} \mathrm{H}$ NMR $\left(300 \mathrm{MHz}, \mathrm{CDCl}_{3}\right) \delta 10.86(\mathrm{~d}, J=$ $1.6 \mathrm{~Hz}, 1 \mathrm{H}), 7.51-7.37(\mathrm{~m}, 6 \mathrm{H}), 7.17(\mathrm{t}, J=1.8 \mathrm{~Hz} 1 \mathrm{H}), 7.15(\mathrm{dd}, J=8.8,2.5 \mathrm{~Hz}, 1 \mathrm{H}), 7.10(\mathrm{t}, J=1.8$ $\mathrm{Hz}, 1 \mathrm{H}), 7.03-6.91(\mathrm{~m}, 3 \mathrm{H}), 6.68(\mathrm{~d}, J=8.8 \mathrm{~Hz}, 1 \mathrm{H}), 5.51(\mathrm{~s}, 2 \mathrm{H}), 4.38(\mathrm{t}, J=6.9 \mathrm{~Hz}, 2 \mathrm{H}), 4.05(\mathrm{t}, J=$ $5.5 \mathrm{~Hz}, 2 \mathrm{H}), 2.45(\mathrm{~m}, 2 \mathrm{H}) .{ }^{13} \mathrm{C}$ NMR $\left(75 \mathrm{MHz}, \mathrm{CDCl}_{3}\right) \delta 152.20$ (1C), 149.83 (1C), 142.64 (1C), 137.75 (1C), 131.08 (1C), 131.05 (1C), 130.16 (1C), 130.15 (1C), 129.57 (2C), 129.01 (2C), 128.23 (1C), 128.09 (1C), 123.91 (1C), 122.50 (1C), 122.01 (2C), 121.02 (1C), 117.99 (1C), 115.29 (1C), 65.20 (1C), 53.69 (1C), 46.92 (1C), 29.56 (1C). HRMS (ES ${ }^{+}$): calcd. for $\mathrm{C}_{25} \mathrm{H}_{22} \mathrm{Cl}_{3} \mathrm{~N}_{2} \mathrm{O}_{2} 487.0747$ [M $\left.-\mathrm{Br}^{-}\right]^{+}$found $487.0745\left[\mathrm{M}-\mathrm{Br}^{-}\right]^{+}$.

2-(3-(3-(5-Chloro-2-(2,4-dichlorophenoxy)phenoxy)propyl)-2,3-dihydro-1H-imidazol-3-

ium)quinoline bromide (1d). To a stirred solution of TC-C3 $(340.7 \mathrm{mg}, 0.82 \mathrm{mmol})$ in $\mathrm{CH}_{3} \mathrm{CN}$ (10 $\mathrm{mL}$ ), 1-(quinoline-2-yl)-1H-imidazole $(113.2 \mathrm{mg}, 0.58 \mathrm{mmol})$ was added and the reaction mixture was stirred 1 day at $70{ }^{\circ} \mathrm{C}$. Then, the solvent was evaporated under reduced pressure and the viscous residue was purified by washing with diethylether to afford a yellow powder (170.3 $\mathrm{mg}, 48 \%$ yield). Anal. Calcd. For $\mathrm{C}_{27} \mathrm{H}_{21} \mathrm{BrCl}_{3} \mathrm{~N}_{3} \mathrm{O}_{2} \mathrm{C}$, 53.54; H, 3.49; N, 6.94. Found C, 53.47; H, 3.58; N, 6.79. ${ }^{1} \mathrm{H}$ NMR $\left(300 \mathrm{MHz}, \mathrm{CDCl}_{3}\right) \delta 12.06(\mathrm{~s}, 1 \mathrm{H}), 8.58(\mathrm{~d}, J=8.8 \mathrm{~Hz}, 1 \mathrm{H}), 8.51(\mathrm{~d}, J=8.5 \mathrm{~Hz}, 1 \mathrm{H}), 8.42(\mathrm{t}, J$ $=1.8 \mathrm{~Hz}, 1 \mathrm{H}), 8.06-8.03(\mathrm{~m}, 1 \mathrm{H}), 7.97-7.94(\mathrm{~m}, 1 \mathrm{H}), 7.85(\mathrm{ddd}, J=8.5,6.9,1.5 \mathrm{~Hz}, 1 \mathrm{H}), 7.68$ (ddd, $J$ $=8.2,6.9,1.2 \mathrm{~Hz}, 1 \mathrm{H}), 7.39(\mathrm{~d}, J=2.5 \mathrm{~Hz}, 1 \mathrm{H}), 7.36(\mathrm{t}, J=1.8 \mathrm{~Hz}, 1 \mathrm{H}), 7.11(\mathrm{dd}, J=8.8,2.5 \mathrm{~Hz}$, $1 \mathrm{H}), 7.02(\mathrm{~d}, J=2.3 \mathrm{~Hz}, 1 \mathrm{H}), 6.95(\mathrm{dd}, J=8.6,2.3 \mathrm{~Hz}, 1 \mathrm{H}), 6.87(\mathrm{~d}, J=8.5 \mathrm{~Hz}, 1 \mathrm{H}), 6.70(\mathrm{~d}, J=8.8$ $\mathrm{Hz}, 1 \mathrm{H}), 4.65(\mathrm{t}, J=6.5 \mathrm{~Hz}, 2 \mathrm{H}), 4.18(\mathrm{t}, J=5.5 \mathrm{~Hz}, 2 \mathrm{H}), 2.65(\mathrm{~m}, 2 \mathrm{H}) .{ }^{13} \mathrm{C}$ NMR $\left(101 \mathrm{MHz}, \mathrm{CDCl}_{3}\right)$ $\delta 152.04$ (1C), 149.71 (1C), 145.96 (1C), 142.90 (1C), 141.63 (2C), 137.01 (1C), 131.51 (1C), 130.78 (1C), 130.19 (1C), 128.82, (1C), 128.54 (1C), 128.29 (1C), 128.14 (3C), 124.34 (1C), 122.63 (1C), 121.87 (1C), 121.35 (1C), 118.64 (1C), 118.34 (1C), 115.09 (1C), 112.76 (1C), 65.66 (1C), 47.89 (1C), 29.69 (1C). HRMS (ES ${ }^{+}$): calcd. for $\mathrm{C}_{27} \mathrm{H}_{21} \mathrm{Cl}_{3} \mathrm{~N}_{3} \mathrm{O}_{2} 524.0669\left[\mathrm{M}-\mathrm{Br}^{-}\right]^{+}$found $524.0667[\mathrm{M}-$ $\left.\mathrm{Br}^{-}\right]^{+}$.

1-(3-(5-chloro-2-(2,4-dichlorophenoxy)phenoxy)propyl)-3-(4-(methylthio)phenyl)-2,3-dihydro$1 \mathrm{H}$-imidazol-3-ium, bromide (1e). To a stirred solution of TC-C3 $(328.4 \mathrm{mg}, 0.80 \mathrm{mmol})$ in $\mathrm{CH}_{3} \mathrm{CN}$ $(10 \mathrm{~mL}), 1-(4-m e t h y l t h i o p h e n y l)-1 H$-imidazole $(121.6 \mathrm{mg}, 0.64 \mathrm{mmol})$ was added and the reaction mixture was stirred 2 days at $70{ }^{\circ} \mathrm{C}$. Then, the solvent was evaporated under reduced pressure and the residue was purified by washing with diethylether to afford a beige powder $(257.0 \mathrm{mg}, 67 \%$ yield). Anal. Calcd. For $\mathrm{C}_{25} \mathrm{H}_{22} \mathrm{BrCl}_{3} \mathrm{~N}_{2} \mathrm{O}_{2} \mathrm{~S} \mathrm{C}, 49.98 ; \mathrm{H}, 3.69 ; \mathrm{N}, 4.66$. Found $\mathrm{C}, 49.85 ; \mathrm{H}, 3.75 ; \mathrm{N}, 4.79 .{ }^{1} \mathrm{H}$ NMR $\left(300 \mathrm{MHz}, \mathrm{CDCl}_{3}\right) \delta 11.32(\mathrm{~d}, J=1.7 \mathrm{~Hz}, 1 \mathrm{H}), 7.66-7.62(\mathrm{~m}, 2 \mathrm{H}), 7.45(\mathrm{~d}, J=2.5 \mathrm{~Hz}, 1 \mathrm{H})$, $7.43(\mathrm{t}, J=1.9 \mathrm{~Hz}, 1 \mathrm{H}), 7.40-7.36(\mathrm{~m}, 3 \mathrm{H}), 7.16(\mathrm{dd}, J=8.8,2.5 \mathrm{~Hz}, 1 \mathrm{H}), 7.03-6.91(\mathrm{~m}, 3 \mathrm{H}), 6.71(\mathrm{~d}$, $J=8.5 \mathrm{~Hz}, 1 \mathrm{H}), 4.63(\mathrm{t}, J=6.8 \mathrm{~Hz}, 2 \mathrm{H}), 4.15(\mathrm{t}, J=5.5 \mathrm{~Hz}, 2 \mathrm{H}), 2.64-2.56(\mathrm{~m}, 2 \mathrm{H}), 2.54(\mathrm{~s}, 3 \mathrm{H}) .{ }^{13} \mathrm{C}$ NMR (101 MHz, $\left.\mathrm{CDCl}_{3}\right) \delta 152.07$ (1C), 149.79 (1C), 142.83 (1C), 142.75 (1C), 136.65 (1C), 131.02 (1C), 130.89 (1C), 130.20 (1C), 128.44 (1C), 128.21 (1C), 127.33 (2C), 124.08 (1C), 123.13 (1C), 122.03 (2C), 121.95 (1C), 121.68 (1C), 119.84 (1C), 118.39 (1C), 115.15 (1C), 65.64 (1C), 47.69 (1C), 29.73 (1C), 15.29 (1C). HRMS (ES ${ }^{+}$): calcd. for $\mathrm{C}_{25} \mathrm{H}_{22} \mathrm{Cl}_{3} \mathrm{~N}_{2} \mathrm{O}_{2} \mathrm{~S} 519.0462\left[\mathrm{M}-\mathrm{Br}^{+}\right]^{+}$found $519.0468\left[\mathrm{M}-\mathrm{Br}^{-}\right]^{+}$.

\section{Synthesis of gold(I) complexes}

Complex 2a. Under a nitrogen atmosphere, $1 \mathbf{a}(50.0 \mathrm{mg}, 0.10 \mathrm{mmol}), \mathrm{K}_{2} \mathrm{CO}_{3}(23.8 \mathrm{mg}, 0.17 \mathrm{mmol})$ and $\mathrm{Au}\left(\mathrm{SMe}_{2}\right) \mathrm{Cl}(18.0 \mathrm{mg}, 0.06 \mathrm{mmol})$ were dissolved in $\mathrm{CH}_{3} \mathrm{CN}(3 \mathrm{~mL})$ and stirred overnight at 60 ${ }^{\circ} \mathrm{C}$. The solution was filtered through a syringe filter $(0.2 \mu \mathrm{m})$ and the solvent removed under reduced pressure to afford a white powder $\left(42.0 \mathrm{mg}, 76 \%\right.$ yield). Anal. Calcd. For $\mathrm{C}_{38} \mathrm{H}_{34} \mathrm{AuBrCl}_{6} \mathrm{~N}_{4} \mathrm{O}_{4} \mathrm{C}$, 41.48; H, 3.11; N, 5.09. Found C, 41.24; H, 3.28; N, 4.89. ${ }^{1} \mathrm{H}$ NMR (400 MHz, DMSO- $\left.d_{6}\right) \delta 7.64(\mathrm{~d}, J$ $=2.6 \mathrm{~Hz}, 1 \mathrm{H}), 7.45(\mathrm{~d}, J=1.8 \mathrm{~Hz}, 1 \mathrm{H}), 7.35(\mathrm{~d}, J=1.8 \mathrm{~Hz}, 1 \mathrm{H}), 7.26(\mathrm{dd}, J=8.9,2.6 \mathrm{~Hz}, 1 \mathrm{H}), 7.22$ $(\mathrm{d}, J=2.3 \mathrm{~Hz}, 1 \mathrm{H}), 7.06(\mathrm{~d}, J=8.6 \mathrm{~Hz}, 1 \mathrm{H}), 7.01(\mathrm{dd}, J=8.6,2.3 \mathrm{~Hz}, 1 \mathrm{H}), 6.75(\mathrm{~d}, J=8.8 \mathrm{~Hz}, 1 \mathrm{H})$, $4.08(\mathrm{t}, J=6.9 \mathrm{~Hz}, 2 \mathrm{H}), 4.01(\mathrm{t}, J=5.8 \mathrm{~Hz}, 2 \mathrm{H}), 3.76(\mathrm{~s}, 3 \mathrm{H}), 2.07(\mathrm{~m}, 2 \mathrm{H}) .{ }^{13} \mathrm{C}$ NMR $(101 \mathrm{MHz}$, $\left.\mathrm{CDCl}_{3}\right) \delta 184.03(1 \mathrm{C}), 152.40$ (1C), 150.32 (1C), 142.68 (1C), 131.02 (1C), $130.12(1 \mathrm{C}), 128.06$ (1C), 127.95 (1C), 123.90 (1C), 122.66 (1C), 122.16 (1C), 122.07 (1C), 121.60 (1C), 117.81 (1C), 115.16 
(1C), 60.40 (1C), 47.56 (1C), 31.00 (1C), 14.21 (1C). HRMS (ES ${ }^{+}$: calcd. for $\mathrm{C}_{38} \mathrm{H}_{34} \mathrm{AuCl}_{6} \mathrm{~N}_{4} \mathrm{O}_{4}{ }^{+}$ 1017.0376 found $1017.0377\left[\mathrm{M}-\mathrm{Br}^{-}\right]^{+}$.

Complex 2b. Under a nitrogen atmosphere, $\mathbf{1 b}(100.0 \mathrm{mg}, 0.17 \mathrm{mmol}), \mathrm{K}_{2} \mathrm{CO}_{3}(35.9 \mathrm{mg}, 0.26 \mathrm{mmol})$ and $\mathrm{Au}\left(\mathrm{SMe}_{2}\right) \mathrm{Cl}(27.1 \mathrm{mg}, 0.09 \mathrm{mmol})$ were dissolved in $\mathrm{CH}_{3} \mathrm{CN}(5 \mathrm{~mL})$ and stirred overnight at 60 ${ }^{\circ} \mathrm{C}$. The solution was filtered through a syringe filter $(0.2 \mu \mathrm{m})$ and the solvent removed under reduced pressure to afford a white powder $\left(101.3 \mathrm{mg}\right.$, 94\% yield). Anal. Calcd. For $\mathrm{C}_{54} \mathrm{H}_{50} \mathrm{AuBrCl}_{6} \mathrm{~N}_{4} \mathrm{O}_{4} \mathrm{C}$, 49.56; H, 3.85; N, 4.28. Found C, 49.58; H, 3.86; N, 4.42. ${ }^{1} \mathrm{H}$ NMR (400 MHz, $\left.\mathrm{CDCl}_{3}\right) \delta 7.58(\mathrm{~d}, J=$ $1.9 \mathrm{~Hz}, 1 \mathrm{H}), 7.43(\mathrm{~d}, J=2.5 \mathrm{~Hz}, 1 \mathrm{H}), 7.17(\mathrm{dd}, J=8.8,2.5 \mathrm{~Hz}, 1 \mathrm{H}), 6.99-6.94(\mathrm{~m}, 3 \mathrm{H}), 6.90-6.89(\mathrm{~m}$, $2 \mathrm{H}), 6.82(\mathrm{~d}, J=1.8 \mathrm{~Hz}, 1 \mathrm{H}), 6.69(\mathrm{~d}, J=8.8 \mathrm{~Hz}, 1 \mathrm{H}), 4.23(\mathrm{t}, J=6.9 \mathrm{~Hz}, 2 \mathrm{H}), 3.92(\mathrm{t}, J=5.9 \mathrm{~Hz}$, 2H), $2.37(\mathrm{~s}, 3 \mathrm{H}), 2.21-2.14(\mathrm{~m}, 2 \mathrm{H}), 1.80(\mathrm{~s}, 6 \mathrm{H}) .{ }^{13} \mathrm{C} \mathrm{NMR}\left(101 \mathrm{MHz}, \mathrm{CDCl}_{3}\right) \delta 183.94(1 \mathrm{C}), 152.26$ (1C), 150.32 (1C), 142.76 (1C), 139.44 (1C), 134.87 (2C), 134.77 (1C), 130.97 (1C), 130.13 (1C), 129.08 (2C), 128.13 (1C), 128.06 (1C), 123.99 (1C), 123.19 (1C), 122.07(1C), 122.04 (1C), 121.69 (1C), 118.04 (1C), 115.18 (1C), 65.05 (1C), 47.80 (1C), 30.84 (1C), 21.16 (1C), 17.55 (2C). HRMS $\left(\mathrm{ES}^{+}\right)$: calcd. for $\mathrm{C}_{54} \mathrm{H}_{50} \mathrm{Cl}_{6} \mathrm{~N}_{4} \mathrm{O}_{4} 1225.1623\left[\mathrm{M}-\mathrm{Br}^{-}\right]^{+}$found $1225.1659[\mathrm{M}-\mathrm{Br}]^{+}$.

Complex 2c. Under a nitrogen atmosphere, 1 c $(110.0 \mathrm{mg}, 0.19 \mathrm{mmol}), \mathrm{K}_{2} \mathrm{CO}_{3}(37.4 \mathrm{mg}, 0.27 \mathrm{mmol})$ and $\mathrm{Au}\left(\mathrm{SMe}_{2}\right) \mathrm{Cl}(29.5 \mathrm{mg}, 0.10 \mathrm{mmol})$ were dissolved in $\mathrm{CH}_{3} \mathrm{CN}(6 \mathrm{~mL})$ and stirred overnight at 60 ${ }^{\circ} \mathrm{C}$. The solution was filtered through a syringe filter $(0.2 \mu \mathrm{m})$ and the solvent removed under reduced pressure to afford a yellow powder $\left(118.5 \mathrm{mg}\right.$, 95\% yield). Anal. Calcd. For $\mathrm{C}_{50} \mathrm{H}_{42} \mathrm{AuBrCl}_{6} \mathrm{~N}_{4} \mathrm{O}_{4} \mathrm{C}$, 47.95; H, 3.38; N, 4.47. Found C, 47.85; H, 3.45; N, 4.34. ${ }^{1} \mathrm{H}$ NMR $\left(300 \mathrm{MHz}, \mathrm{CDCl}_{3}\right) \delta 7.40(\mathrm{~d}, J=$ $2.5 \mathrm{~Hz}, 1 \mathrm{H}), 7.33-7.28(\mathrm{~m}, 3 \mathrm{H}), 7.20-7.15(\mathrm{~m}, 3 \mathrm{H}), 7.12(\mathrm{dd}, J=8.9,2.5 \mathrm{~Hz}, 1 \mathrm{H}), 7.01(\mathrm{~d}, J=1.9 \mathrm{~Hz}$, $1 \mathrm{H}), 6.96-6.92(\mathrm{~m}, 3 \mathrm{H}), 6.64(\mathrm{~d}, J=8.8 \mathrm{~Hz}, 1 \mathrm{H}), 5.35(\mathrm{~s}, 2 \mathrm{H}), 4.25(\mathrm{t}, J=6.9 \mathrm{~Hz}, 2 \mathrm{H}), 3.94(\mathrm{t}, J=5.5$ $\mathrm{Hz}, 2 \mathrm{H}), 2.24(\mathrm{~m}, 2 \mathrm{H}) .{ }^{13} \mathrm{C}$ NMR $\left(101 \mathrm{MHz}, \mathrm{CDCl}_{3}\right) \delta 183.99$ (1C), 152.37 (1C), 150.31 (1C), 142.67 (1C), 135.66 (1C), 131.01 (1C), 130.11 (1C), 129.03 (2C), 128.50 (1C), 128.05 (1C), 127.97 (1C), 127.33 (2C), 123.92 (1C), 122.54 (1C), 122.12 (2C), 121.61 (1C), 117.86 (1C), 115.20 (1C), 65.44 (1C), 54.84 (1C), 47.91 (1C), 30.91 (1C). HRMS (ES ${ }^{+}$): calcd. for $\mathrm{C}_{50} \mathrm{H}_{42} \mathrm{AuCl}_{6} \mathrm{~N}_{4} \mathrm{O}_{4} 1169.0997$ [M $\left.\mathrm{Br}^{-}\right]^{+}$found $1169.1025\left[\mathrm{M}-\mathrm{Br}^{-}\right]^{+}$.

Complex 2d. Under a nitrogen atmosphere and protection of the light, 1d $(63.0 \mathrm{mg}, 0.104 \mathrm{mmol})$, $\mathrm{K}_{2} \mathrm{CO}_{3}(20.2 \mathrm{mg}, 0.15 \mathrm{mmol})$ and $\mathrm{Au}\left(\mathrm{SMe}_{2}\right) \mathrm{Cl}(18.4 \mathrm{mg}, 0.06 \mathrm{mmol})$ were dissolved in $\mathrm{CH}_{3} \mathrm{CN}(3$ $\mathrm{mL})$ and stirred overnight at $60{ }^{\circ} \mathrm{C}$. The solution was filtered through a syringe filter $(0.2 \mu \mathrm{m})$ and the solvent removed under reduced pressure to afford a white powder $(65.4 \mathrm{mg}, 95 \%$ yield). Anal. Calcd. For $\mathrm{C}_{54} \mathrm{H}_{40} \mathrm{AuBrCl}_{6} \mathrm{~N}_{6} \mathrm{O}_{4} \mathrm{C}, 51.09 ; \mathrm{H}, 3.23 ; \mathrm{N}, 5.15$; Found C, 48.95; H, 3.25; N, 6.42. ${ }^{1} \mathrm{H}$ NMR (400 $\left.\mathrm{MHz}, \mathrm{CDCl}_{3}\right) \delta 8.36(\mathrm{~d}, J=8.6 \mathrm{~Hz}, 1 \mathrm{H}), 8.06(\mathrm{~d}, J=8.4 \mathrm{~Hz}, 1 \mathrm{H}), 7.89(\mathrm{~d}, J=8.8 \mathrm{~Hz}, 1 \mathrm{H}), 7.87(\mathrm{~d}, J=$ $1.9 \mathrm{~Hz}, 1 \mathrm{H}), 7.72-7.68(\mathrm{~m}, 2 \mathrm{H}), 7.56-7.50(\mathrm{~m}, 1 \mathrm{H}), 7.39(\mathrm{~d}, J=2.1 \mathrm{~Hz}, 1 \mathrm{H}), 7.38(\mathrm{~d}, J=2.5 \mathrm{~Hz}, 1 \mathrm{H})$, $7.11(\mathrm{dd}, J=8.8,2.5 \mathrm{~Hz}, 1 \mathrm{H}), 7.02-6.91(\mathrm{~m}, 3 \mathrm{H}), 6.64(\mathrm{~d}, J=8.8 \mathrm{~Hz}, 1 \mathrm{H}), 4.43(\mathrm{t}, J=6.9 \mathrm{~Hz}, 2 \mathrm{H})$, $3.97(\mathrm{t}, J=5.5 \mathrm{~Hz}, 2 \mathrm{H}), 2.39-2.32(\mathrm{~m}, 2 \mathrm{H}) .{ }^{13} \mathrm{C} \mathrm{NMR}\left(101 \mathrm{MHz}, \mathrm{CDCl}_{3}\right) \delta 182.17(1 \mathrm{C}), 152.32(1 \mathrm{C})$, 150.26 (1C), 149.29 (1C), 146.28 (1C), 142.67 (1C), 139.56 (1C), 131.00 (1C), 130.87 (1C), 130.13 (1C), 128.60 (1C), 128.07 (1C), 127.95 (1C), 127.79 (1C), 127.63 (1C), 127.42 (1C), 123.99 (1C), 122.98 (1C), 122.02 (1C), 121.61 (1C), 121.00 (1C), 117.90 (1C), 116.36 (1C), 115.20 (1C), 65.46 (1C), 48.86 (1C), 30.77 (1C). HRMS (ES $)$ : calcd. for $\mathrm{C}_{54} \mathrm{H}_{40} \mathrm{AuCl}_{6} \mathrm{~N}_{6} \mathrm{O}_{4} 1243.0920$ found 1243.0908 $[\mathrm{M}-\mathrm{Br}]^{+}$.

Complex 2e. Under a nitrogen atmosphere and protection of the light, 1e (100.0 $\mathrm{mg}, 0.17 \mathrm{mmol})$, $\mathrm{K}_{2} \mathrm{CO}_{3}(32.2 \mathrm{mg}, 0.24 \mathrm{mmol})$ and $\mathrm{Au}\left(\mathrm{SMe}_{2}\right) \mathrm{Cl}(23.6 \mathrm{mg}, 0.085 \mathrm{mmol})$ were dissolved in $\mathrm{CH}_{3} \mathrm{CN}(6$ $\mathrm{mL})$ and stirred overnight at $60{ }^{\circ} \mathrm{C}$. The solution was filtered through a syringe filter $(0.2 \mu \mathrm{m})$ and the solvent removed under reduced pressure to afford a yellow powder $(104.0 \mathrm{mg}, 99 \%$ yield). Anal. Calcd. For $\mathrm{C}_{50} \mathrm{H}_{42} \mathrm{AuBrCl}_{6} \mathrm{~N}_{4} \mathrm{O}_{4} \mathrm{~S}_{2} \mathrm{C}, 45.61 ; \mathrm{H}, 3.22 ; \mathrm{N}, 4.26$. Found $\mathrm{C}, 45.56 ; \mathrm{H}, 3.52 ; \mathrm{N}, 4.36$. ${ }^{1} \mathrm{H}$ NMR $\left(400 \mathrm{MHz}, \mathrm{CDCl}_{3}\right) \delta 7.46(\mathrm{dt}, J=7.0,2.3 \mathrm{~Hz}, 2 \mathrm{H}), 7.42(\mathrm{~d}, J=1.9 \mathrm{~Hz}, 1 \mathrm{H}), 7.39(\mathrm{~d}, J=2.5 \mathrm{~Hz}$, $1 \mathrm{H}), 7.26-7.21(\mathrm{~m}, 2 \mathrm{H}), 7.16(\mathrm{~d}, J=1.9 \mathrm{~Hz}, 1 \mathrm{H}), 7.13(\mathrm{dd}, J=8.8,2.5 \mathrm{~Hz}, 1 \mathrm{H}), 7.02-6.95(\mathrm{~m}, 3 \mathrm{H})$, $6.66(\mathrm{~d}, J=8.8 \mathrm{~Hz}, 1 \mathrm{H}), 4.29(\mathrm{t}, J=7.0 \mathrm{~Hz}, 2 \mathrm{H}), 4.00(\mathrm{t}, J=5.5 \mathrm{~Hz}, 2 \mathrm{H}), 2.53(\mathrm{~s}, 3 \mathrm{H}), 2.27(\mathrm{~m}, 2 \mathrm{H})$. ${ }^{13} \mathrm{C}$ NMR (101 MHz, $\left.\mathrm{CDCl}_{3}\right) \delta 182.38$ (1C), 152.35 (1C), 150.37 (1C), 142.55 (1C), 140.69 (1C), 135.82 (1C), 131.10 (1C), 130.10 (1C), 128.20 (1C), 128.00 (1C), 126.36 (2C), 125.39 (2C), 123.84 (1C), 123.13 (1C), 122.18 (1C), 121.87 (1C), 121.62 (1C), 117.79 (1C), 115.18 (1C), 65.71 (1C), 48.33 (1C), 30.82 (1C), 15.39(1C). HRMS (ES ${ }^{+}$: calcd. for $\mathrm{C}_{50} \mathrm{H}_{42} \mathrm{AuCl}_{6} \mathrm{~N}_{4} \mathrm{O}_{4} \mathrm{~S}_{2} 1233.0439$ found $1233.0455[\mathrm{M}-\mathrm{Br}]^{+}$.

Complex 3. In a pressure flask, imidazole (3.32 g, $48.8 \mathrm{mmol})$, 2-chloroquinoline (4 g, $24.4 \mathrm{mmol}, 0.5$ eq.), $\mathrm{K}_{2} \mathrm{CO}_{3}\left(3.37 \mathrm{~g}, 24.4 \mathrm{mmol}, 0.5\right.$ eq.) and a catalytic amount of $\mathrm{CuSO}_{4}$ were heated at $200{ }^{\circ} \mathrm{C}$ and 
stirred for $2.5 \mathrm{~h}$. After cooling to room temperature, the brown precipitate formed was dissolved in a mixture of $\mathrm{CHCl}_{3}$ and $\mathrm{CH}_{2} \mathrm{Cl}_{2}$ 1:1. After filtration through a pad of celite, the solution was evaporated and dried under vacuum to give 2-(1H-imidazol-1-yl)quinoline as a beige powder ( $3.95 \mathrm{~g}, 83 \%$ yield). $250 \mathrm{mg}(1.281 \mathrm{mmol})$ of 2-(1H-imidazol-1-yl)quinoline and $0.162 \mathrm{~mL}(1.409 \mathrm{mmol}, 1.1 \mathrm{eq}$.) of benzyl chloride were dissolved in dry $\mathrm{CH}_{3} \mathrm{CN}(10 \mathrm{~mL})$ and stirred at $80{ }^{\circ} \mathrm{C}$ for $12 \mathrm{~h}$. The solution was evaporated and dried under vacuum to give 3-benzyl-1-(quinolin-2-yl)-1H-imidazol-3-ium chloride as a yellow powder $\left(400 \mathrm{mg}, 97 \%\right.$ yield). Anal. Calcd. For $\mathrm{C}_{19} \mathrm{H}_{16} \mathrm{ClN}_{3} \mathrm{C}, 70.91 ; \mathrm{H}, 5.01 ; \mathrm{N}, 13.06$. Found C, 70.83, H, 5.11, N, 13.12. ${ }^{1} \mathrm{H}$ NMR $\left(400 \mathrm{MHz}, \mathrm{DMSO}-d_{6}\right): \delta 10.57(\mathrm{~d}, J=1.6 \mathrm{~Hz}, 1 \mathrm{H}), 8.84$ $(\mathrm{d}, J=8.8 \mathrm{~Hz}, 1 \mathrm{H}), 8.72(\mathrm{dd}, J=1.9 \mathrm{~Hz}, 1 \mathrm{H}), 8.21(\mathrm{~d}, J=8.8 \mathrm{~Hz}, 1 \mathrm{H}), 8.19-8.15(\mathrm{~m}, 1 \mathrm{H}), 8.12(\mathrm{dd}, J$ $=1.9 \mathrm{~Hz}, 1 \mathrm{H}), 8.09(\mathrm{~d}, J=8.5 \mathrm{~Hz}, 1 \mathrm{H}), 7.95(\mathrm{ddd}, J=8.5,6.9,1.5 \mathrm{~Hz}, 1 \mathrm{H}), 7.77(\mathrm{ddd}, J=8.2,6.9$, $1.2 \mathrm{~Hz}, 1 \mathrm{H}), 7.58(\mathrm{~d}, J=6.0 \mathrm{~Hz}, 2 \mathrm{H}), 7.48-7.42(\mathrm{~m}, 3 \mathrm{H}), 5.62(\mathrm{~s}, 2 \mathrm{H}) .{ }^{13} \mathrm{C}$ NMR $\left(75 \mathrm{MHz}, \mathrm{CDCl}_{3}\right): \delta$ 146.03 (1C), 144.55 (1C), 141.58 (1C), 137.18 (1C), 132.73 (1C), 131.40 (1C), 129.68 (1C), 129.54 (2C), 129.28 (2C), 128.77 (1C), 128.25 (1C), 128.09 (1C), 128.02 (1C), 121.67 (1C), $118.91(1 \mathrm{C})$, 112.76 (1C), 54.07 (1C). HRMS $\left(\mathrm{ES}^{+}\right)$: calcd. for $\mathrm{C}_{19} \mathrm{H}_{16} \mathrm{~N}_{3} 286.1344$ found $286.1344[\mathrm{M}-\mathrm{Cl}]^{+}$. Under a nitrogen atmosphere and protection of light, $214 \mathrm{mg}(0.67 \mathrm{mmol})$ of the carbene precursor and $77.1 \mathrm{mg}$ ( $0.33 \mathrm{mmol}, 0.5$ eq.) of $\mathrm{Ag}_{2} \mathrm{O}$ were dissolved in $12 \mathrm{~mL}$ of dry acetonitrile and stirred at room temperature for 12 hours. After that, $98 \mathrm{mg}\left(0.33 \mathrm{mmol}, 0.5 \mathrm{eq}\right.$.) of $\mathrm{Au}\left(\mathrm{SMe}_{2}\right) \mathrm{Cl}$ were added and stirred in the same conditions for 2 hours. The suspension obtained was filtered through a pad of celite

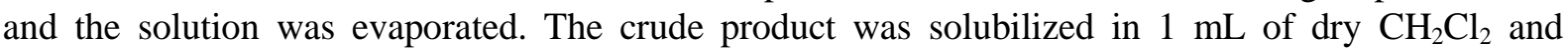
precipitated with $8 \mathrm{~mL}$ of diethyl ether. After filtration, complex 3 was obtained as a beige powder (217 mg, 81\% yield). Anal. Calcd. For $\mathrm{C}_{38} \mathrm{H}_{30} \mathrm{AuN}_{6} \mathrm{Cl} \mathrm{C}, 56.83 ; \mathrm{H}, 3.77 ; \mathrm{N}, 10.46$; Found C, 56.69; H, 3.80; N, 10.41. ${ }^{1} \mathrm{H}$ NMR $\left(400 \mathrm{MHz}, \mathrm{CD}_{3} \mathrm{CN}\right) \delta 8.04(\mathrm{~d}, \mathrm{~J}=2.5 \mathrm{~Hz}, 2 \mathrm{H}), 7.96(\mathrm{~d}, \mathrm{~J}=2.0 \mathrm{~Hz}, 1 \mathrm{H}), 7.81$ $(\mathrm{d}, J=8.9 \mathrm{~Hz}, 1 \mathrm{H}), 7.78(\mathrm{~d}, J=7.4 \mathrm{~Hz}, 1 \mathrm{H}), 7.68$ (ddd, $J=8.4,6.9,1.5 \mathrm{~Hz}, 1 \mathrm{H}), 7.55$ (ddd, $J=8.1$, $7.0,1.2 \mathrm{~Hz}, 1 \mathrm{H}), 7.48(\mathrm{~d}, J=2.0 \mathrm{~Hz}, 1 \mathrm{H}), 7.29(\mathrm{~m}, 5 \mathrm{H}), 5.51(\mathrm{~s}, 2 \mathrm{H}) \cdot{ }^{13} \mathrm{C} \mathrm{NMR}\left(101 \mathrm{MHz}, \mathrm{CD}_{3} \mathrm{CN}\right) \delta$ 182.66 (1C), 149.26 (1C), 146.13 (1C), 139.53 (1C), 136.06 (1C), 130.98 (1C), 128.88 (2C), 128.39 (1C), 128.30 (1C), 127.89 (1C), 127.57 (1C), 127.45 (2C), 127.42 (1C), 122.89 (1C), 121.68 (1C), $115.66(1 \mathrm{C}), 55.23$ (1C). HRMS (ES $)^{+}$: calcd. for $\mathrm{C}_{38} \mathrm{H}_{30} \mathrm{AuN}_{6} 767.2197$ found $767.2199[\mathrm{M}-\mathrm{Cl}]^{+}$.

\section{Crystallographic data for $2 a$}

All data were collected at low temperature using oil-coated shock-cooled crystals on a Bruker-AXS APEX II diffractometer with MoK $\alpha$ radiation $(\lambda=0.71073 \AA)$. The structures were solved by direct methods ${ }^{[32]}$ and all non hydrogen atoms were refined anisotropically using the least-squares method on F. ${ }^{2[33]}$

Crystal data for 2a at $100(2) \mathrm{K}: \mathrm{C}_{42} \mathrm{H}_{44} \mathrm{AuBrCl}_{6} \mathrm{~N}_{4} \mathrm{O}_{5}, M=1174.39$, monoclinic, $P 2_{1} / \mathrm{c}, a=19.069$ (4), $b=12.200(3), c=19.853(5) \AA, b=102.513(8)^{\circ}, V=4508(2) \AA^{3}, Z=4, D_{\text {calcd }}=1.730 \mathrm{~g} / \mathrm{cm}^{3}, R=$ $0.0486\left(I_{o}>2 \sigma\left(I_{o}\right)(w R 2=0.1190\right.$ for all data $)$, GOF $=1.030$. CCDC-1960111 (2a) contain the supplementary crystallographic data. These data can be obtained free of charge from The Cambridge Crystallographic Data Centre via www.ccdc.cam.ac.uk/data_request/cif.

\section{Plasmodium falciparum culture}

The Plasmodium falciparum strains, F32-ART resistant to artemisinins and its twin sensitive to artemisinins F32-TEM ${ }^{[7]}$ from the parental strain F32-Tanzania, were cultivated in vitro as described by Trager and Jensen ${ }^{[34]}$ with minor modifications. ${ }^{[35]}$ Briefly, parasites were grown in type O human erythrocytes (Etablissement Français de sang (EFS), Toulouse, France), diluted to 2\% hematocrit and suspended in RPMI-1640 medium (GIBCO, France) with 5\% Human Serum AB (EFS, Toulouse, France) at $37^{\circ} \mathrm{C}$ and $5 \% \mathrm{CO}_{2}$.

Parasite cultures were synchronized at the ring stage using $5 \%$ sorbitol solution ${ }^{[36]}$ every other day and before each experiment.

\section{Evaluation of antimalarial chemosensitivity}


P. falciparum drug susceptibility assays were performed using 2 different method. Firstly, the chemosensitivity assays were carried out by SYBR Green in 96-well flat bottom sterile plates by the addition of $100 \mu \mathrm{L}$ of the aforementioned parasites solution then $100 \mu \mathrm{L}$ of RPMI 5\% SH-diluted drugs (triplicate wells). Negative controls such as parasites treated with solvents (DMSO or RPMI), and positive controls of parasites treated by artemether, were added to each set of experiments.

DNA in treated and control cultures of parasites were quantified using the SYBR Green (ThermoFischer) fluorescence-based method after $48 \mathrm{~h}$ of incubation with the drugs (Smilkstein, Sriwilaijaroen, Kelly, Wilairat, \& Riscoe, 2004). Briefly, pellets were washed three times with PBS and frozen at $-20^{\circ} \mathrm{C}$ until use. Plates were then thawed at room temperature, and $100 \mu \mathrm{l}$ of each homogenized culture were transferred to a 96-well black plate that contained $100 \mu \mathrm{l}$ of the SYBR Green lysis buffer $(20 \mathrm{~mm}$ Tris base $\mathrm{pH} 7.5,5 \mathrm{~mm}$ EDTA, $0.008 \% \mathrm{w} / \mathrm{v}$ saponin, $0.08 \% \mathrm{w} / \mathrm{v}$ Triton X100). Plates were incubated for $2 \mathrm{~h}$ at room temperature and then read on a fluorescence plate reader (FLx800, BioTek) using excitation and emission wavelengths of 485 and $535 \mathrm{~nm}$, respectively.

To confirm the results obtained with the SYBR Green method, the standard chemosensitivity assay recommended by the WHO and based on the incorporation of $\left[{ }^{3} \mathrm{H}\right]$ hypoxanthine by the parasites was then performed at least one time for each molecule. The radioactivity assay was carried out according to the description of Desjardins et al ${ }^{[37]}$ with some modifications. ${ }^{[35]}$ After $24 \mathrm{~h}$ of incubation with the drug dilutions, $\left[{ }^{3} \mathrm{H}\right]$ hypoxanthine $(50 \mu \mathrm{l} /$ well/ $0.25 \mu \mathrm{Ci}$; Perkin-Elmer $)$ was added. The plates were incubated under the same conditions for another $24 \mathrm{~h}$. After that, plates were frozen at $-20^{\circ} \mathrm{C}$ and thawed at room temperature. This step leads to the release of the nucleic acids which were collected on filters. The filters were dried and placed with $5 \mathrm{ml}$ of scintillation fluid (Perkin-Elmer). Tritium incorporation was then determined with a $\beta$-counter (Perkin-Elmer).

Concentrations inhibiting $50 \%$ of the parasite's growth (half maximal inhibitory concentration or $\mathrm{IC}_{50}$ values) were then calculated from the obtained experimental results using GraphPad Prism software 7 (GraphPad Software, San Diego, CA, USA). Data reported in Table 1 correspond to the mean of at least 4 values of $\mathrm{IC}_{50}$ from independent experiments, obtained both by SYBR Green and by radioactivity.

\section{Cytotoxicity assays regarding antimalarial activity}

Cytotoxicity of the selected compounds according their antiplasmodial activity, was determined thanks to a previously described method with some modifications. ${ }^{[38]}$ The Vero cell line (monkey epithelial cell line) was cultured in MEM medium (Dutscher, France) supplemented with $10 \%$ fetal bovine serum (Dutscher, France), $0.7 \mathrm{mM}$ glutamine and $100 \mu \mathrm{g} / \mathrm{ml}$ gentamicin (Sigma).

The cells were plated onto 96-well plates in $100 \mu \mathrm{L}$ and seeded at $10^{4}$ cells per well. Following $24 \mathrm{~h}$ of incubation at $37{ }^{\circ} \mathrm{C}$ and $5 \% \mathrm{CO}_{2}$, cells were incubated for an additional $48 \mathrm{~h}$ with various concentrations of the compounds to be tested $(100 \mu \mathrm{L}$ per well). The cell proliferation was measured with MTT (1-(4,5-dimethylthiazol-2-yl)-3,5-diphenylformazan, Sigma). Briefly, $100 \mu \mathrm{L}$ of MTT solution $(0.5 \mathrm{mg} / \mathrm{mL}$ in MEM) was added to each well and the plate was further incubated for $1 \mathrm{~h}$ at $37{ }^{\circ} \mathrm{C}$ and $5 \% \mathrm{CO}_{2}$. Subsequently, the cells and MTT crystals were dissolved in $100 \mu \mathrm{L}$ of DMSO with the help of a plate shaker. The absorbance was measured at $540 \mathrm{~nm}$ ( $\mu$ Quant, BioTek). Cell proliferation was calculated from at least 3 independent experiments using GraphPad Prism software 7 (GraphPad Software, San Diego, CA, USA). Selectivity index was then calculated and corresponds to the ratio of cytotoxicity $\mathrm{IC}_{50}$ value / activity $\mathrm{IC}_{50}$ value.

\section{Recrudescence assay}

D-sorbitol synchronized ring-form cultures of F32-ART and F32-TEM at $3 \%$ parasitemia and $2 \%$ hematocrit were exposed to drugs to be tested for $48 \mathrm{~h}$ then washed with RPMI-1640 medium and finally placed in new wells in drug-free culture conditions with $10 \%$ human serum. The parasitemia 
was then monitored daily to determine the time required for each parasite culture to recover the initial parasitemia $(3 \%)$. If there was no recrudescence up to 30 days, the cultures were discarded and the parasites were considered as "not recrudescent". ${ }^{[7,39]}$ A preliminary drug screening (range from 1-fold to $>100$-fold the antiplasmodial $\mathrm{IC}_{50}$ value) enabled determination of the most appropriate dose of drugs to discriminate the phenotype response of both lines in the recrudescence assay in order to evaluate possible cross-resistance of the drugs tested with artemisinins.

\section{Statistical analysis}

Statistical tests were performed using GraphPad Prism 7 software (GraphPad Software, San Diego, CA, USA). Results of recrudescence assay were subjected to normality analysis with Shapiro-Wilk. Statistical significance was determined by a log-rank (Mantel-Cox) test. $P$-value $<0.05$ was considered as the level of statistical significance.

\section{Antileishmanial evaluation}

Leishmania species used in this study is Leishmania infantum strain MHOM/MA/67/ITMAP-263 (CNR Leishmania, Montpellier, France) expressing luciferase activity. ${ }^{[40]}$

\section{Antileishmanial activity on promastigotes}

The effects of the tested compounds on the growth of L. infantum promastigotes were evaluated by Luciferase Assay ${ }^{\circledR}$. Promastigotes in log-phase in RPMI 1640 medium supplemented with $10 \%$ fetal calf serum, $2 \mathrm{mM}$ l-glutamine and antibiotics $(100 \mathrm{U} / \mathrm{mL}$ penicillin, $100 \mu \mathrm{g} / \mathrm{mL}$ streptomycin and $50 \mu \mathrm{g} / \mathrm{mL}$ geneticin), were incubated at a density of $10^{6}$ parasites $/ \mathrm{mL}$ in sterile 96 -well plates with various concentrations of compounds dissolved in DMSO (final concentration less than $0.5 \% \mathrm{v} / \mathrm{v}$ ), in duplicate. Appropriate controls DMSO, amphotericin B, miltefosine and pentamidine (reference drugs purchased from Sigma Aldrich) were added to each set of experiments. After a $72 \mathrm{~h}$ incubation period at $24{ }^{\circ} \mathrm{C}$, each plate-well was then microscope-examined for detecting possible precipitate formation. To estimate the luciferase activity of promastigotes, $80 \mu \mathrm{l}$ of each well are transferred in white 96-well plates after mild resuspension, Steady Glow $^{\circledR}$ reagent (Promega) was added according to manufacturer's instructions, and plates were incubated for $2 \mathrm{~min}$ at room temperature. The luminescence was measured in Microbeta Luminescence Counter (PerkinElmer). Inhibitory concentration $50 \%\left(\mathrm{IC}_{50}\right)$ was defined as the concentration of drug required to inhibit by $50 \%$ the metabolic activity of $L$. infantum promastigotes compared to the control. IC $_{50}$ were calculated by nonlinear regression analysis processed on dose-response curves, using TableCurve $2 \mathrm{D}$ V5 software. $\mathrm{IC}_{50}$ values represent the mean value calculated from three independent experiments.

\section{Antileishmanial activity on axenic amastigotes}

L. Infantum promastigotes in logarithmic phase were centrifuged at $900 \mathrm{~g}$ for $10 \mathrm{~min}$; the supernatant was removed carefully and was replaced by the same volume of RPMI 1640 complete medium at $\mathrm{pH}$ 5.4 and incubated for $24 \mathrm{~h}$ at $24^{\circ} \mathrm{C}$. The acidified promastigotes were incubated for $24 \mathrm{~h}$ at $37{ }^{\circ} \mathrm{C}$ in a ventilated flask. Promastigotes were then transformed into amastigotes. The effects of the tested compounds on the growth of L. infantum axenic amastigotes were assessed as follows. L. Infantum amastigotes were incubated at a density of $2.10^{6}$ parasites $/ \mathrm{mL}$ in sterile 96 -well plates with various concentrations of compounds dissolved in DMSO (final concentration less than $0.5 \% \mathrm{v} / \mathrm{v}$ ), in duplicate. Appropriate controls DMSO, amphotericin B, miltefosine and pentamidine were added to each set of experiments. After a $48 \mathrm{~h}$ incubation period at $37^{\circ} \mathrm{C}$, each plate-well was then microscopeexamined for detecting any precipitate formation. The luciferase activity of axenic amastigotes was estimated as aforementioned for promastigotes. 


\section{Cytotoxicity assays regarding antileishmanial activity}

The cytotoxicity of the molecules was evaluated by MTT assay on the J774A.1 cell line (mouse macrophage cell line, Sigma-Aldrich). Briefly, cells $\left(5 \times 10^{4}\right.$ cells $\left./ \mathrm{mL}\right)$ in $100 \mu \mathrm{L}$ of complete medium [DMEM high Glucose supplemented with $10 \%$ fetal calf serum, $2 \mathrm{mM}$ 1-glutamine and antibiotics (100 U/mL penicillin and $100 \mu \mathrm{g} / \mathrm{mL}$ streptomycin)] were seeded into each well of 96-well plates and incubated at $37{ }^{\circ} \mathrm{C}$ and $5 \% \mathrm{CO}_{2}$. After a $24 \mathrm{~h}$ of incubation, $100 \mu \mathrm{L}$ of medium with various product concentrations and appropriate controls treated by DMSO, amphotericin $\mathrm{B}$, miltefosine, doxorubicine and pentamidine (reference drugs purchased from Sigma Aldrich) were added and the plates were incubated for $72 \mathrm{~h}$ at $37{ }^{\circ} \mathrm{C}$ and $5 \% \mathrm{CO}_{2}$. Each plate-well was then microscope-examined for detecting possible precipitate formation before the medium was aspirated from the wells. One hundred $\mu \mathrm{L}$ of MTT solution $(0.5 \mathrm{mg} / \mathrm{mL}$ in DMEM) were then added to each well. Cells were incubated for $2 \mathrm{~h}$ at $37{ }^{\circ} \mathrm{C}$ and $5 \% \mathrm{CO}_{2}$. After this time, the MTT solution was removed and DMSO (100 $\left.\mu \mathrm{l} / \mathrm{well}\right)$ was added to dissolve the resulting crystals. Plates were shaken vigorously $(300 \mathrm{rpm})$ for $5 \mathrm{~min}$. The absorbance was measured at $570 \mathrm{~nm}$ with a microplate spectrophotometer (Eon BioTek). DMSO was used as blank. $\mathrm{CC}_{50}$ values were calculated by non-linear regression analysis processed on doseresponse curves, using TableCurve $2 \mathrm{D}$ V5 software. $\mathrm{CC}_{50}$ values represent the mean value calculated from three independent experiments.

\section{Acknowledgments}

This study was supported in part by the French "Agence Nationale de la Recherche" (ANR grant INMAR ANR16 CE35 0003) and the "Centre National de la Recherche Scientifique".

\section{REFERENCES}

[1] World Health Organisation. World Malaria Report. 2018.

[2] WHO GMP, Ringwald Status report on artemisinin and ACT resistance September. 2015.

[3] Wongsrichanalai C, Meshnick SR, Emerg Infect Dis. 2008, 14, 716 - 719.

[4] Amato R, Lim P, Miotto O, Amaratunga C, Dek D, Pearson RD, Almagro-Garcia J, Neal AT, Sreng S, Suon S, Drury E, Jyothi D, Stalker J, Kwiatkowski DP, Fairhurst RM, Lancet Infect Dis. 2017, 17, $164-173$.

[5] Witkowski B, Duru V, Khim N, Ross LS, Saintpierre B, Beghain J, Chy S, Kim S, Ke S, Kloeung N, Eam R, Khean C, Ken M, Loch L, Bouillon A, Domergue A, Ma L, Bouchier C, Leang R, Huy R, Nuel G, Barale JC, Legrand E, Ringwald P, Fidock DA, Mercereau-Puijalon O, Ariey F, Ménard D, Lancet Infect Dis. 2017, 17, 174 - 183.

[6] World Health Organization. Status Report on Artemisinin an ACT Resistance (April 2017). 2017.

[7] Witkowski B, Lelièvre J, Barragán MJL, Laurent V, Su XZ, Berry A, Benoit-Vical F, Antimicrob Agents Chemother. 2010, 54, 1872 - 1877.

[8] Ariey F, Witkowski B, Amaratunga C, Beghain J, Langlois AC, Khim N, Kim S, Duru V, Bouchier C, Ma L, Lim P, Leang R, Duong S, Sreng S, Suon S, Chuor CM, Bout DM, Ménard S, Rogers WO, Genton B, Fandeur T, Miotto O, Ringwald P, Le Bras J, Berry A, Barale JC, Fairhurst RM, Benoit-Vical F, Mercereau-Puijalon O, Ménard D, Nature. 2014, $505,50-55$

[9] Teuscher F, Gatton ML, Chen N, Peters J, Kyle DE, Cheng Q, J Infect Dis. 2010, 202, 1362 1368

[10] Intharabut B, Kingston HW, Srinamon K, Ashley EA, Imwong M, Dhorda M, Woodrow C, Stepniewska K, Silamut K, Day NPJ, Dondorp AM, White NJ, Tracking Resistance to Artemisinin Collaboration, J Infect Dis. 2019, 219, 1483 - 1489.

[11] Chen N, LaCrue AN, Teuscher F, Waters NC, Gatton ML, Kyle DE, Cheng Q, Antimicrob 
Agents Chemother. 2014, 58, 4773 - 4781.

[12] Waller RF, Keeling PJ, Donald RG, Striepen B, Handman E, Lang-Unnasch N, Cowman AF, Besra GS, Roos DS, McFadden GI, Proc Natl Acad Sci U S A. 1998, 95, 12352 - 12357.

[13] Botté CY, Dubar F, McFadden GI, Maréchal E, Biot C. Plasmodium falciparum Apicoplast Drugs: Targets or Off-Targets? Chem Rev. 2012, 12, 1269-1283.

[14] Peatey CL, Chavchich M, Chen N, Gresty KJ, Gray KA, Gatton ML, Waters NC, Cheng Q, J Infect Dis. 2015, 212, 426 - 434.

[15] Bindoli A, Rigobello MP, Scutari G, Gabbiani C, Casini A, Messori L, Coord Chem Rev. 2009, 253, 1692 - 1707.

[16] Boselli L, Ader I, Carraz M, Hemmert C, Cuvillier O, Gornitzka H. Synthesis, structures, and selective toxicity to cancer cells of gold(I) complexes involving $\mathrm{N}$-heterocyclic carbene ligands, Eur J Med Chem. 2014, 85, 87 - 94.

[17] Gupta R, Felix C, Akerman MP, Akerman KJ, Slabber CA, Wang W, Adams J, Shaw LN, TseDinh YC, Munro OQ, Rohde KH, Antimicrob Agents Chemother. 2018, 62, doi: 10.1128/AAC.01696-17.

[18] Ruth MM, van Rossum M, Koeken VACM, Pennings LJ, Svensson EM, Ruesen C, Bowles EC, Wertheim HFL, Hoefsloot W, van Ingen J, Antimicrob Agents Chemother. 2019, 63, doi: 10.1128/AAC.00449-19.

[19] Hemmert C, Fabié A, Fabre A, Benoit-Vical F, Gornitzka H, Eur J Med Chem. 2013, 60, 64 75.

[20] Hemmert C, Ramadani AP, Boselli L, Fernández Álvarez Á, Paloque L, Augereau , Gornitzka H, Benoit-Vical F, Bioorganic Med Chem. 2016, 24, 3075 - 3082.

[21] Paloque L, Hemmert C, Valentin A, Gornitzka H, Eur J Med Chem. 2015, 94, 22 - 29.

[22] Zhang C, Bourgeade Delmas S, Fernández Álvarez Á, Valentin A, Hemmert C, Gornitzka H, Eur J Med Chem. 2018, 143, 1635 -1643.

[23] Akhoundi M, Downing T, Votýpka J, Kuhls K, Lukeš J, Cannet A, Ravel C, Marty P, Delaunay P, Kasbari M, Granouillac B, Gradoni L, Sereno D, Mol Aspects Med. 2017, 57, 1 $-19$.

[24] World Health Organisation. Leishmaniasis; Magnitude of the problem. 2019.

[25] Reithinger R, Dujardin JC, Louzir H, Pirmez C, Alexander B, Brooker S, Lancet Infect Dis. 2007, 7, 581 - 596.

[26] Chappuis F, Sundar S, Hailu A, Ghalib H, Rijal S, Peeling RW, Alvar J, Boelaert M, Nat Rev Microbiol. 2007, 5, 873 - 882.

[27] Croft SL, Olliaro P, Clin Microbiol Infect. 2011, 17, 1478 - 1483.

[28] Rubbiani R, Kitanovic I, Alborzinia H, Can S, Kitanovic A, Onambele LA, Stefanopoulou M, Geldmacher Y, Sheldrick WS, Wolber G, Prokop A, Wölfl S, Ott I, J Med Chem. 2010, 53, $8608-8618$.

[29] Navarro M, Coord Chem Rev. 2009, 253, 1619 - 1626.

[30] Strassner T, Unger Y, Zeller A, PCT Int Appl. 2008, WO 2008/000726A1.

[31] Otero E, Vergara S, Robledo SM, Cardona W, Carda M, Vélez ID, Rojas C, Otálvaro F, Molecules. 2014, 19, 13251 - 13266.

[32] Sheldrick GM, Acta Crystallogr Sect A Found Crystallogr. 2008, 64, 112 - 122.

[33] Sheldrick GM, Acta Crystallogr Sect C Struct Chem. 2015, 71, 3 - 8.

[34] Trager W, Jensen JB, Science. 1976, 193, 673 - 675.

[35] Benoit-Vical F, Lelièvre J, Berry A, Deymier C, Dechy-Cabaret O, Cazelles J, Loup C, Robert A, Magnaval JF, Meunier B, Antimicrob Agents Chemother. 2007, 51,1463 - 1472.

[36] Lambros C, Vanderberg JP, J Parasitol. 1979, 65, 418 - 420.

[37] Desjardins RE, Canfield CJ, Haynes JD, Chulay JD, Antimicrob Agents Chemother. 1979, 16, $710-718$.

[38] Tengchaisri T, Chawengkirttikul R, Rachaphaew N, Reutrakul V, Sangsuwan R, Sirisinha S, Cancer Lett. 1998, 133, 169 - 175.

[39] Ménard S, Ben Haddou T, Ramadani AP, Ariey F, Iriart X, Beghain J, Bouchier C, Witkowski B, Berry A, Mercereau-Puijalon O, Benoit-Vical F, Emerg Infect Dis. 2015, 21, 1733 - 1741.

[40] Sereno D, Roy G, Loup Lemesre J, Papadopoulou B, Ouellette M, Antimicrob Agents Chemother. 2001, 45, 1168 - 1173 . 
[41] Surolia N, Surolia A, Nat Med. 2001, 7, 167 - 173.

[42] Witkowski B, Khim N, Chim P, Kim S, Ke S, Kloeung N, Chy S, Duong S, Leang R, Ringwald P, Dondorp AM, Tripura R, Benoit-Vical F, Berry A, Gorgette O, Ariey F, Barale JC, Mercereau-Puijalon O, Menard D, Antimicrob Agents Chemother. 2013, 57, 914 - 23. 